\title{
Contrasting impacts of climate change on the vegetation of windy ridges and snowbeds in the Swiss Alps
}

\author{
Loïc Liberati ${ }^{1,2}$, Swanee Messerli ${ }^{1,3}$, Magalì Matteodo ${ }^{1,4}$ \& Pascal Vittoz ${ }^{1^{*}}$ \\ ${ }^{1}$ University of Lausanne, Faculty of Geosciences and Environment, Institute of Earth Surface Dynamics, \\ Géopolis, 1015 Lausanne, Switzerland \\ ${ }^{2}$ ETH Zürich, Institute of Integrative Biology, Department of Environmental Systems Science, Building \\ CHN, Universitätstrasse 16, 8092 Zürich, Switzerland \\ ${ }^{3}$ Route des Esserts 61, 1854 Leysin, Switzerland \\ ${ }^{4}$ Chemin de Bonne-Espérance 28, 1006 Lausanne, Switzerland
}

Corresponding author: Pascal Vittoz, University of Lausanne, FGSE, Institute of Earth Surface Dynamics, Géopolis, 1015 Lausanne, Switzerland; +41 21692 4367; pascal.vittoz@unil.ch

ORCID:

Magalì Matteodo: https://orcid.org/0000-0003-3813-5261

Pascal Vittoz: https://orcid.org/0000-0003-4218-4517

\begin{abstract}
The impacts of climate change on alpine summit floras have been widely investigated. However, only few studies included alpine grasslands and generally concluded that snowbeds, with a long snow cover duration and a short growing season, and windy ridges, with a short snow cover duration and strong winter frosts, are the most sensitive alpine grasslands. However, these habitats were mostly investigated in different regions, where local factors (e.g., nitrogen deposition, grazing) can co-vary with climate changes, potentially obscuring differences between habitats. Here, we focused on the Zermatt region (Swiss Alps) to investigate the impacts of climate change in snowbeds and on windy ridges.

Forty-three exhaustive historical plant inventories on windy ridges (acidophilic or basophilic) and 31 inventories in snowbeds (typical or wet) were repeated in quasi-permanent plots after approximately 23 years. Historical and recent records were compared with the Simpson index, Bray-Curtis dissimilarity, a PCA, ecological indicator values and the frequency and cover changes of species.

There was a general increase in $\alpha$-diversity and a decrease in $\beta$-diversity (homogenisation). Most of the new species in the plots were generalists from surrounding grasslands. The plant composition tended to be more thermophilous on acidophilic windy ridges and in typical snowbeds. The flora of acidophilic windy ridges became more similar to that of basophilic windy ridges and more eutrophic. We interpreted this as possibly arising from fertilisation by the aeolian dust deposition coming from the expanding glacial moraine in the valley. In snowbeds, the species indicated increasingly drier conditions, especially in wet snowbeds. Warming climate induces lower snow fall and earlier snowmelt, leading to a shorter snow cover duration. Hence, wet snowbeds are certainly among the plant communities most threatened by climate change in the Alps.
\end{abstract}

Keywords: Salicion herbaceae, Elynion, snow cover, temperature, quasi-permanent plots, vegetation dynamics, Switzerland

\footnotetext{
* Declaration of authorship: all authors designed the study, LL and SM inventoried the plots in the fields and analysed the data under the advices of MM and PV, all authors contributed to the manuscript.
} 


\section{Acknowledgements}

We are grateful to J.-L. Richard, B. Bressoud, C. Käsermann, S. Krähenmann, F. Meyer and S. Reist who collected the historical data, to A. Steiner who transmitted them to us, to M. Vust for his help in lichen identification and to J. Alexander for English editing. We also thank the Burgergemeinde Zermatt for authorising this study on their properties and the Zermatt Bergbahnen AG for offering the travelling costs for the cable cars during fieldwork.

\section{Introduction}

Climate is one of the main drivers of the distribution of vegetation in the alpine and nival mountain belts. Human impact is low at these elevations, and the snow cover duration and the mean and minimum temperatures are among the most important factors controlling species distribution (Körner 2003). Consequently, the climatic changes recorded in the last decades (Stocker et al. 2013; Klein et al. 2016) have already had a strong impact on species distributions in alpine-nival belts, particularly on high mountain summits, with a general increase in species richness (e.g., Pauli et al. 2012; Matteodo et al. 2013; Steinbauer et al. 2018).

Snow cover extent and duration depend on elevation and on topography, with an important redistribution of snow by wind (Körner 2003). As a consequence, the differences in snow cover duration in spring can be up to 11 weeks between very close sites at the same elevation because of microtopography or aspect (Friedel 1961). It is well known that plant distribution in high mountains follows this snow pattern, as a long snow cover period reduces the growth season down to the limits of plant survival and, conversely, the short snow cover period on ridges exposes plants to deep frost in winter (Körner 2003). As the snow cover duration tends to decrease at all elevations with climate change (Klein et al. 2016), one can expect that plant communities in both extreme conditions, i.e. very long and very short snow cover periods, are particularly sensitive to climate change.

A few recent studies have indeed concluded that species composition in snowbeds, with a long snow cover duration, and on windy ridges, with a short snow cover duration, have already changed under climate change. Matteodo et al. (2016) concluded that these two vegetation types are among the most sensitive ones to climate change, with clear changes in the last 25-40 years, whereas calcareous and siliceous grasslands occupying intermediate conditions relative to snow cover did not change. Similarly, Gritsch et al. (2016) in Austria and Carbognani et al. (2014) in Italy observed that snowbeds are particularly sensitive to climate change, with a general colonisation of species from surrounding grasslands. These authors concluded that the shorter snow cover period, due to a decrease in snowfall and an earlier melt under warmer spring temperatures (Serquet et al. 2013; Klein et al. 2016), was the best explanation for the observed changes. Apart from the study of Matteodo et al. (2016), changes on windy ridges have been addressed only outside of the Alps, mainly at higher latitudes, and the conclusions of these studies are mixed. Elumeeva et al. (2013) noted only small changes in the Caucasus, while Virtanen et al. (2003) and Vanneste et al. (2017) recorded an increase of dwarf shrubs in Scandinavia, although the opposite was observed by Ross et al. (2012) in Scotland, where graminoids are replacing dwarf shrubs. All authors agreed on a general decline of lichens, an important component of windy ridges, but explained this pattern differently, attributing it to reindeer grazing (Virtanen et al. 2003; Maliniemi et al. 2018), nitrogen deposition (Armitage et al. 2014), competition with vascular plants, especially dwarf shrubs (Vanneste et al. 2017) or trampling and climate change (Ross et al. 2012). These different explanations show the importance of other local factors (e.g., grazing and nitrogen deposition) and how they can influence the impact of climate change on vegetation (Vittoz et al. 2009b; Maliniemi et al. 2018). 
Until now, only a few studies have addressed the impact of climate change on these two habitats in a single region: Matteodo et al. (2016) in the Alps, but with a restricted data set, and Maliniemi et al. (2018) in Scandinavia. Moreover, the regions considered by these two past studies were still broad enough to allow local conditions to vary considerably. Only a restricted area, sharing similar land use and exposure to pollution, is likely to provide a good understanding of vegetation responses to climate change. The aim of this study was to assess climate change impact on snowbeds and windy ridges over more than 20 years with a large dataset in the same valley. For this, we repeated 23-year-old phytosociological relevés in 34 snowbeds and on 43 windy ridges, all situated in the Zermatt Valley in the Swiss Alps. Based on previous studies, we hypothesised a general increase of thermophilous species and grasses in both habitats and a flora indicating dryer conditions in snowbeds.

\section{Materials and methods}

Study site

The study was performed in the central Alps of Switzerland, in the Zermatt valley (Fig. 1). This site is characterised by a large variety of geological materials, such as gneiss, granite, calcschists, marble and ophiolite (Käsermann et al. 2003). The lower slopes are mostly covered by glacial moraines or colluvial and aeolian deposits. This diversity induces a large range of soil pH. Due to the 29 peaks exceeding $4000 \mathrm{~m}$ a.s.l. around the valley, it is one of the most continental and dry places in the Alps given its elevation (Richard 1991). The mean annual temperature is $4.4^{\circ} \mathrm{C}$ in Zermatt $\left(1638 \mathrm{~m}\right.$; between $-4.2^{\circ} \mathrm{C}$ in January and $13.4^{\circ} \mathrm{C}$ in July), and has been increasing by $0.25^{\circ} \mathrm{C}$ per decade for the last 30 years (Fig. 2a). The annual sum of precipitation amounts to $639 \mathrm{~mm}$, including $274 \mathrm{~cm}$ of fresh snow per year. In winter, snow covers the ground for an average of 142 days in Zermatt, disappearing between midMarch and the beginning of May, with a mean advance of 3 days per decade (Fig. 2b; www.meteoswiss.ch).

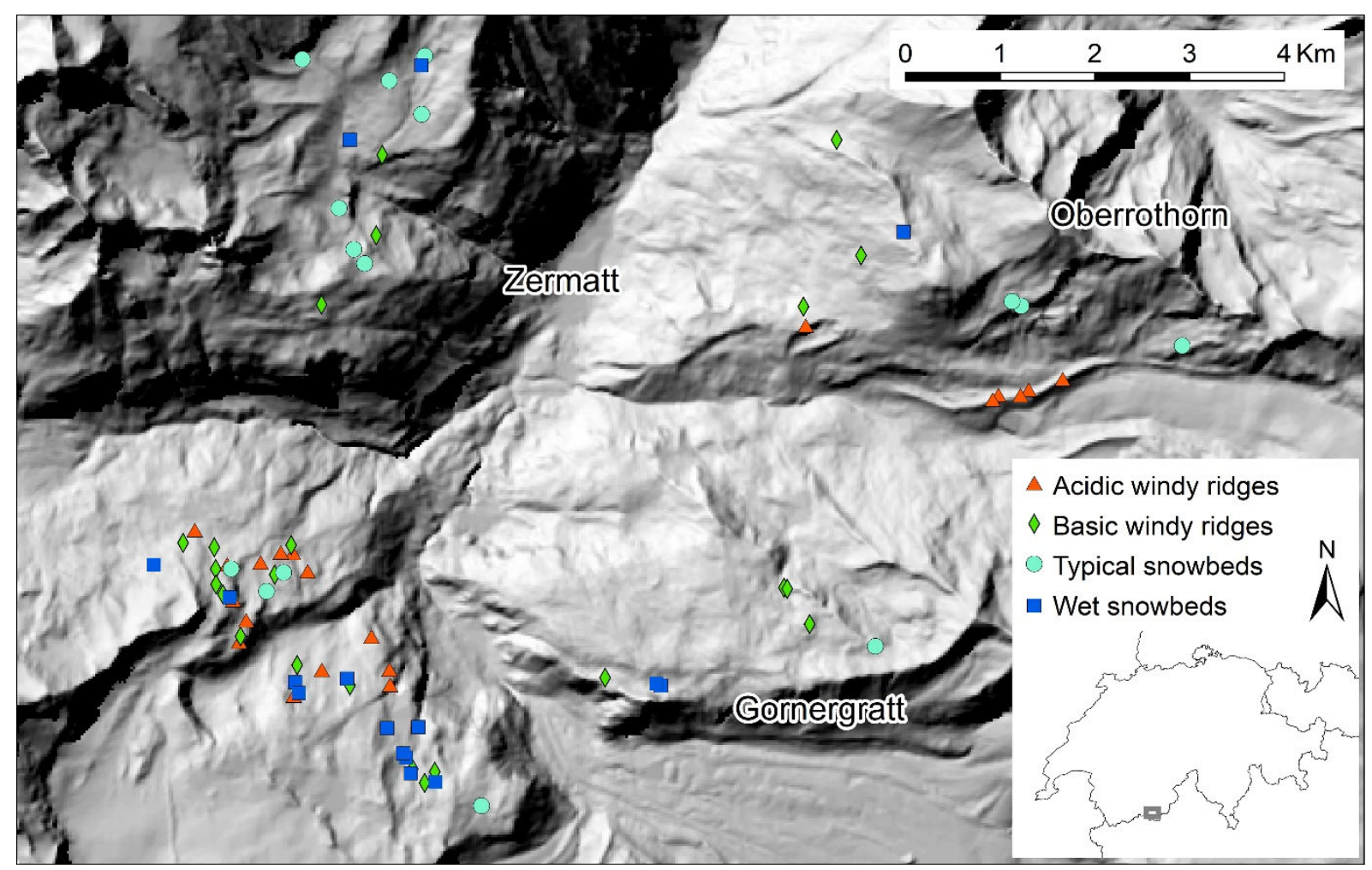

Fig. 1 The distribution of the 74 relevés in the Zermatt Valley. The grey rectangle in the inset shows the location of Zermatt in Switzerland. 

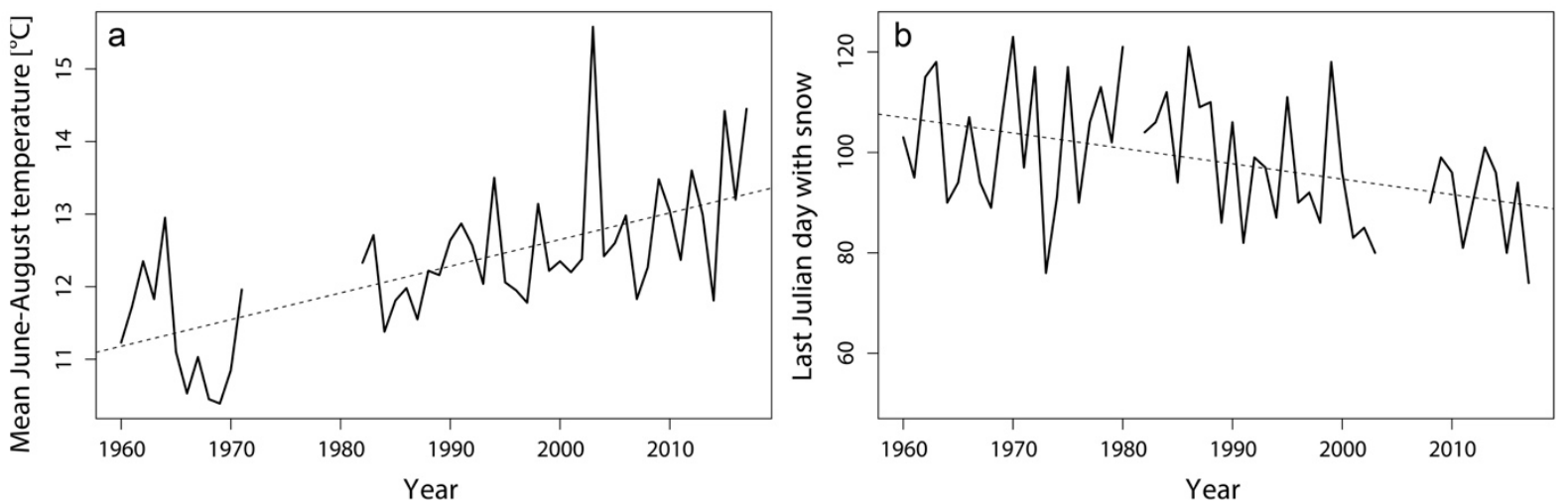

Fig. 2 (a) Summer (June-August) mean temperatures between 1960 and 2017 and (b) last day (counted from the $1^{\text {st }}$ of January) with snow in Zermatt (1636 m a.s.I.; data www.meteoswiss.ch). Both trends are significant ( $p<$ 0.001 for summer temperature, $p=0.002$ for the last day with snow cover).

\section{Vegetation data}

Hundreds of exhaustive floristic inventories (relevés) were conducted by several botanists around Zermatt between 1970 and 1995 and were classified into community types by Steiner (2002). Historical relevés of windy ridges $(n=186)$ and snowbeds $(n=65)$ were extracted from this dataset. To obtain a broad perspective on the dynamics of these vegetation types, we selected historical plots covering contrasting soil pH for windy ridges (acidophilic and basophilic) and soil humidity for snowbeds (typical and wet). Windy ridges are generally classified in the phytosociological alliance Oxytropo-Elynion (Prunier et al. 2017); they correspond to locations where strong winds regularly sweep out the snow in winter, exposing species to deep frosts during most of the winter (Körner 2003). Two plant associations were retained: the Elyno-Caricetum rosae on basic substrate and the Elynetum myosuroidis on acidic substrate (Prunier et al. 2017). Conversely, the snowbeds are characterised by a very long snow cover duration, reducing the growing season to less than 3 months. The typical snowbeds are in hollows, on north-facing slopes or on the leeward side of ridges. They belong to the alliance Salicion herbaceae, in which three associations were retained: Salicetum herbaceae (middle conditions), Caricetum foetidae (depressions with short waterlogging) and Polytrichetum sexangularis (very long snow cover duration). The wet snowbeds are continuously irrigated by melt-water from a firn, small river, or lake throughout the short growth season. The two retained associations were the Salici herbaceae-Caricetum lachenalii (in Salicion herbaceae), on soil rich in organic matter, and the Junco triglumis-Caricetum bicoloris (in Caricion bicoloris-atrofuscae), in pioneer conditions (Prunier et al. 2017). The main species of the respective associations are listed in the Appendix (Table S1).

Only plots with precise location information were retained, generally a point on a topographic map (1:25'000), mostly completed by field notes (describing exposure, slope, surface) and, in a few cases, by a photograph. For windy ridges, plots with a historical inventory of lichens were also preferentially selected. In the field, once the plot was approximately located, the surface with a species composition most similar to the historical relevé was selected for a conservative approach. When no surface corresponded correctly to the historical data (vegetation or site description), the site was discarded. For snowbeds, as historical relevés were often small (1-4 $\left.\mathrm{m}^{2}\right)$, when different surfaces were possible in the same site, two or three new plots with similar conditions to the historical relevé were selected and inventoried. Thereafter, all new inventories were compared to the historical one with the Bray-Curtis dissimilarity, and the most similar one was retained for further analyses. Hence, the data can be considered as quasi-permanent plots (Kapfer et al. 2017). In total, 43 plots from windy ridges (21 to 36 years old, mean 23 years) and 31 plots from snowbeds ( 21 to 45 years old, mean 23 years) were reinventoried throughout the Zermatt valley, from July to August 2016. They were located between 2410 and $2943 \mathrm{~m}$ a.s.l. for windy ridges and between 2455 and $2920 \mathrm{~m}$ a.s.l. for snowbeds (see Appendix, Table S2, for details). 
All vascular plants were recorded (nomenclature according to Lauber et al. 2012), and complemented with terricolous lichen species on windy ridges (nomenclature according to Clerc \& Truong 2012). We adopted the same method as for the historical dataset, with a visual cover estimation according to Braun-Blanquet's scale (1964). The inventoried area was identical to the historical relevé, and the new plot was marked with aluminium plates in the soil, and the precise coordinates of the four corners were recorded ( $\pm 1 \mathrm{~m}$ GPS Trimble GeoXH) for future inventories.

\section{Data analyses}

Data preparation and analyses were similar to Matteodo et al. (2016), with a conversion of the BraunBlanquet scale to the median of the cover range $(r \rightarrow 0.05,+\rightarrow 0.5,1 \rightarrow 3,2 \rightarrow 15,3 \rightarrow 37.5,4 \rightarrow$ $62.5,5 \rightarrow 87.5)$ to compare species cover between relevés, and a conversion to an ordinal scale $(r \rightarrow$ $0.1,+\rightarrow 0.5,1 \rightarrow 1,2 \rightarrow 2, \ldots)$ for the other analyses. Clustering using the Hellinger distance and the Ward aggregation algorithm was used to separate the data sets (windy ridges or snowbeds) into subunits. The Simpson index was used to investigate changes in $\alpha$-diversity through time and the difference between historical and recent medians was tested with a pairwise Wilcoxon-Mann-Witney test. A possible homogenisation was addressed by calculating, within each vegetation type, the mean Bray-Curtis dissimilarity between each historical inventory and all other historical inventories, and between each recent inventory and all other recent inventories. The difference between medians of historical and recent dissimilarities was tested with a pairwise Wilcoxon-Mann-Witney test.

The differences in species frequency and cover between historical and recent relevés were tested by permutation tests following Kapfer et al. (2011), as detailed in Matteodo et al. (2016), with each randomisation being limited within one vegetation type. All the species were included in the frequency change analyses, but only the species present in at least $25 \%$ of the historical and recent surveys were considered for the cover change analyses.

We used the mean Landolt ecological indicator values (Landolt et al. 2010), calculated and weighted by species cover for each plot, to investigate potential associations between ecological factors and the observed vegetation changes. Significant changes in mean indicator values by vegetation type and period were checked using pairwise Wilcoxon-Mann-Witney tests for temperature (T), light (L), continentality $(K)$, soil humidity $(F)$, soil pH $(R)$, nutrient content $(N)$ and humus content $(H)$.

Vegetation shifts between historical and recent inventories were assessed by principal components analysis (PCA, R vegan library), separately for windy ridges and snowbeds and based on the species cover, which had been submitted to Hellinger transformation (Borcard et al. 2011). For each vegetation type, the shift between historical and new relevés along the two first axes was tested with a MANOVA, applied to the differences of axis scores against the intercept (Vittoz et al. 2009b).

All data processing and analyses were performed using the R statistical software (version 3.4.3, R Core Team 2017).

\section{Results}

All pairs of historical and recent relevés were maintained in the same group following cluster analysis, very close to each other in the dendrogram, except one plot, which shifted from wet to typical snowbeds (Appendix, Fig. S1).

\section{Diversity}

Our data showed extremely strong differences in the frequency and composition of lichens between historical and recent data on windy ridges. Added to the fact that many occurrences in the historical data set were identified only at the genus level, we had to conclude that the historical data were most likely not complete enough for a valid comparison. Hence, lichens were not included in the analyses. 
The $\alpha$-diversity of vascular plants increased in 36 of 43 plots for windy ridges and in 27 of 31 plots in snowbeds from historical to recent inventories. The mean Simpson index increased significantly in snowbeds ( $+4.1 \pm 2.8$ for typical snowbeds, $p<0.001 ;+4.0 \pm 3.7$ for wet snowbeds, $p<0.001$ ) and on windy ridges $(+3.5 \pm 4.0$ for acidophilic ridges, $p=0.001 ;+2.2 \pm 4.7$ for basophilic ridges, $p=0.004 ;$ Fig. 3 ). At the same time, $\beta$-diversity (Bray-Curtis dissimilarity) decreased for 38 plots on windy ridges and for 18 plots in snowbeds. The mean index decreased significantly in acidophilic $(-0.067 \pm 0.035, p<$ $0.001)$ and basophilic windy ridges $(-0.020 \pm 0.037, p=0.007)$ and in typical snowbeds $(-0.049 \pm 0.065$, $p=0.005$; Fig. 4), but was stable in wet snowbeds.
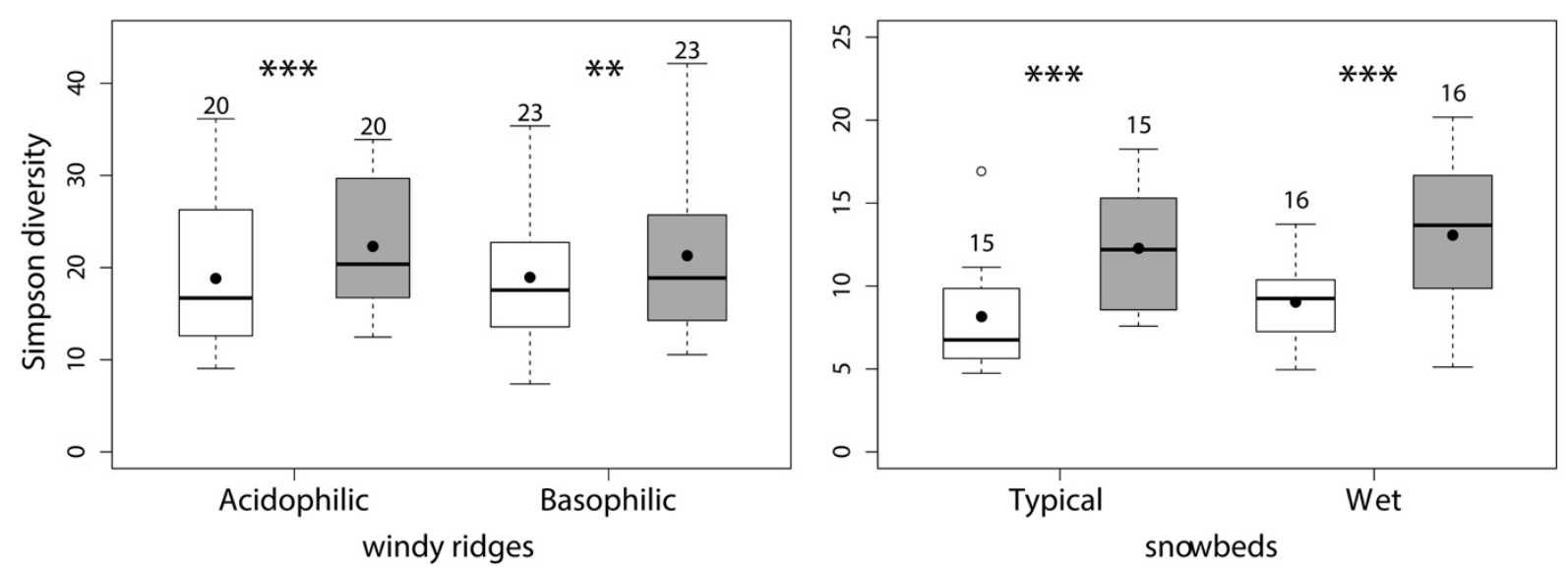

Fig. 3 Simpson diversity indices for historical (white boxes) and recent (grey boxes) inventories of vascular plant species on windy ridges and in snowbeds. Black dots represent the mean values, the black line is the median, and boxes delimit the $1^{\text {st }}$ and $3^{\text {rd }}$ quartiles. Stars above the boxes indicate a significant difference between historical and recent inventories, according to a pairwise Wilcoxon-Mann-Whitney test: ${ }^{*} p<0.05,{ }^{*} p<0.01$, $* * * p<0.001$. The numbers above boxplots are the sample sizes.
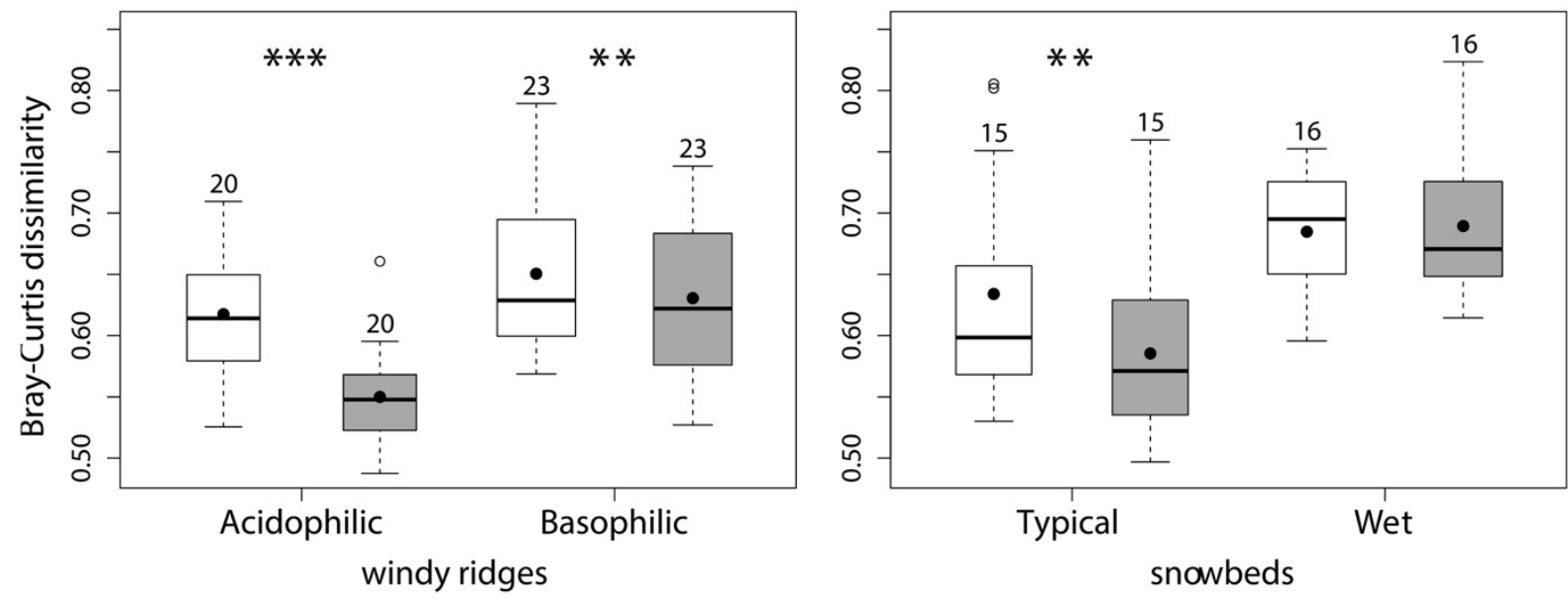

Fig. 4 Bray-Curtis dissimilarity indices, calculated for each inventory with all the other inventories of the same period and habitat, among historical (white boxes) and recent (grey boxes) inventories of vascular plant species on windy ridges and in snowbeds. Symbols are the same as in Figure 3.

\section{Changes in species composition and cover}

The first two axes of the PCA based on windy ridge inventories explained $13 \%$ of the total variance (PC1: 6.8\%, PC2: 6.2\%). Recent and historical relevés were almost always situated closely together, corresponding to a weak change in composition and cover (Fig. 5a). Nevertheless, the acidophilic windy ridges showed a significant mean temporal shift $(p=0.016$ with a MANOVA) in the direction of 
basophilic windy ridges. These latter ones showed no significant change in species composition and cover. A significant shift was also detected for wet snowbeds towards typical snowbeds $(p=0.023$; Fig. $5 b$ ) according to the PCA, whose first two axes explained $17.0 \%$ of the total variance (PC1: $11.8 \%, P C 2$ : $5.2 \%)$. The typical snowbeds did not show any significant shift.
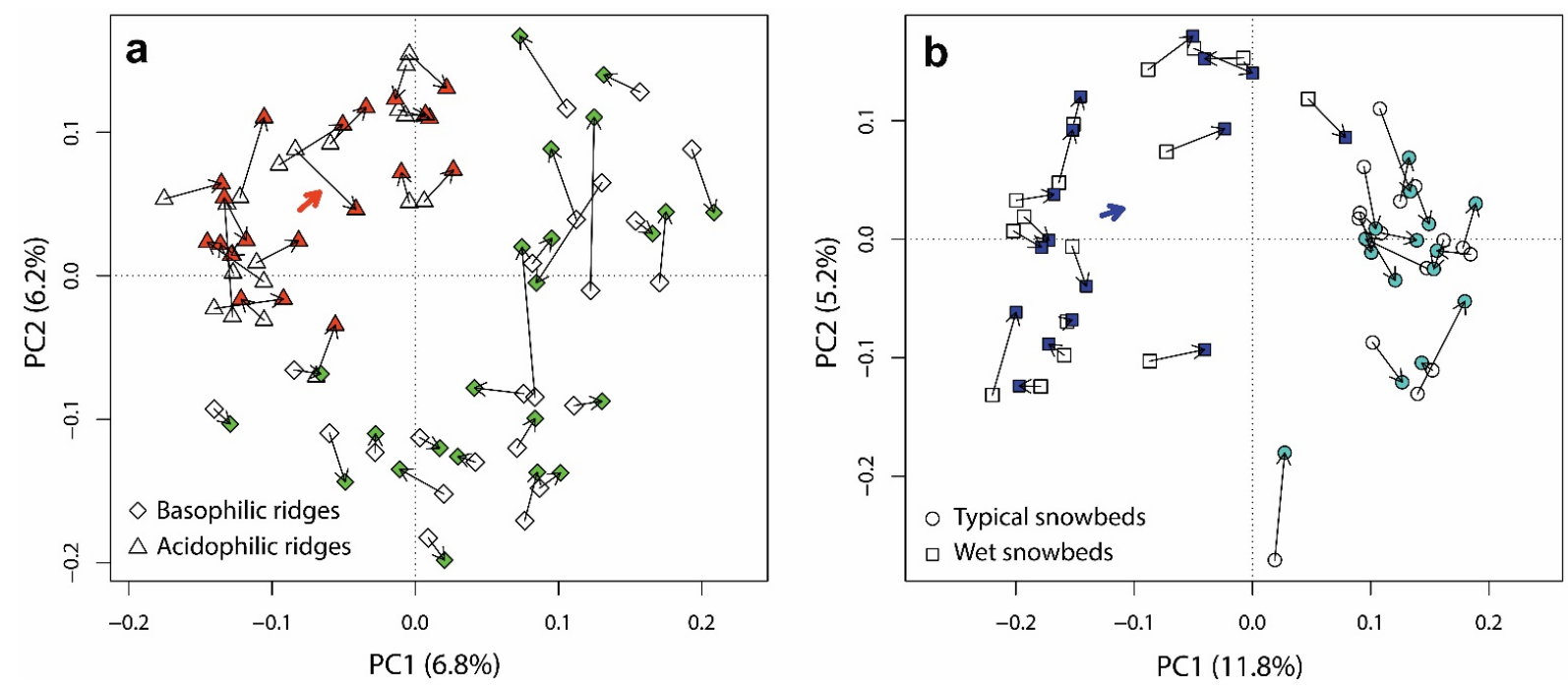

Fig. 5 Principal components analyses based on the composition and cover of vascular plant species (a) on windy ridges and (b) in snowbeds. Couples of historical (empty symbols) and recent (full symbols) surveys are connected with arrows. The thick arrows represent a significant shift of the plant community centroids, i.e. for (a) acidophilic windy ridges and (b) wet snowbeds.

\section{Species frequency and cover changes}

In both habitats, there were more species whose frequencies increased between inventories than species with a decreased frequency (Table S3-S6), and only increasing frequencies were statistically significant. On acidophilic windy ridges (Table S3), only the relative frequency of Euphrasia minima increased significantly $(+47 \%, p=0.002)$. As an annual species, its populations can fluctuate widely from year to year. On basophilic windy ridges (Table S4), the frequencies of a typical graminoid for this habitat (Agrostis alpina; $+29 \%, \mathrm{p}=0.023$ ) and of two generalists (Euphrasia minima; $+38 \%$; Campanula scheuchzeri, $+29 \%$ ) increased significantly ( $p=0.004$ and $p=0.009$, respectively). In both habitats, several species from windy ridges (e.g., Phyteuma hemisphaericum, Veronica aphylla, Salix serpillifolia) and other grasslands (e.g., Poa alpina, Leontodon helveticus, Erigeron uniflorus, Festuca violacea aggr.) increased in frequency, but not significantly. Sesleria caerulea was the only species with a significant increase in cover $(+6.7 \%, p=0.030)$ on basophilic windy ridges. Conversely, Carex ericetorum decreased in frequency $(-21 \%)$, although only marginally significantly $(p=0.099)$.

In typical snowbeds (Table S5), Festuca halleri aggr. and Leontodon helveticus, species from acidophilic alpine grasslands, increased in frequency (both $+40 \%, p=0.027$ and $p=0.020$, respectively). Sagina saginoides, a typical snowbed species, similarly increased $(p=0.003)$. Some snowbed species (e.g., Veronica alpina, Gnaphalium supinum), grasslands species (e.g., Festuca violacea aggr., Agrostis schraderiana) and Cirsium spinosissimum increased in frequency, although not significantly. Other snowbed species (Carex foetida, Salix herbacea, Alchemilla pentaphyllea) decreased in cover, but never significantly. On wet snowbeds (Table S6), only Veronica alpina and Leontodon helveticus increased in frequency (both $+38 \%, p=0.020$ and $p=0.022$ ), while increases of other grassland species were not significant in terms of frequency (e.g., Campanula scheuchzeri, Carex sempervirens, Pedicularis kerneri) or cover (e.g., Carex capillaris, Festuca rubra aggr.). Two typical species of this plant community decreased, but not significantly: Carex lachenalii decreased in frequency (-19\%) and Carex bicolor in cover $(-11 \%)$. 


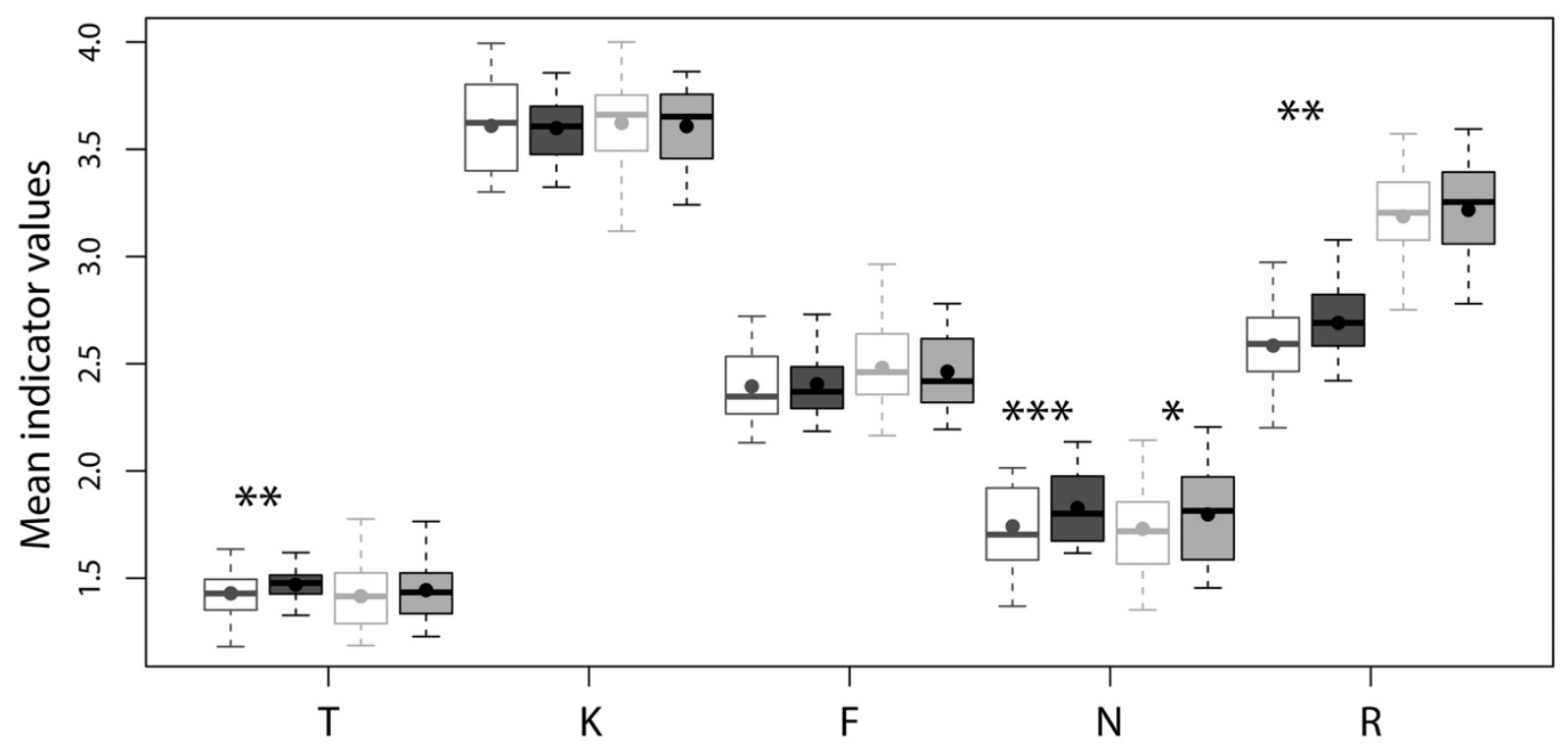

Fig. 6 Cover-weighted means of ecological indicator values (Landolt et al. 2010) for temperature (T), continentality $(K)$, soil humidity $(F)$, nutrient content $(N)$ and $\mathrm{pH}(\mathrm{R})$ in historical (white boxes) and recent inventories of vascular plant species on acidophilic (dark grey) and basophilic (light grey) windy ridges. Symbols are the same as in Figure 3.

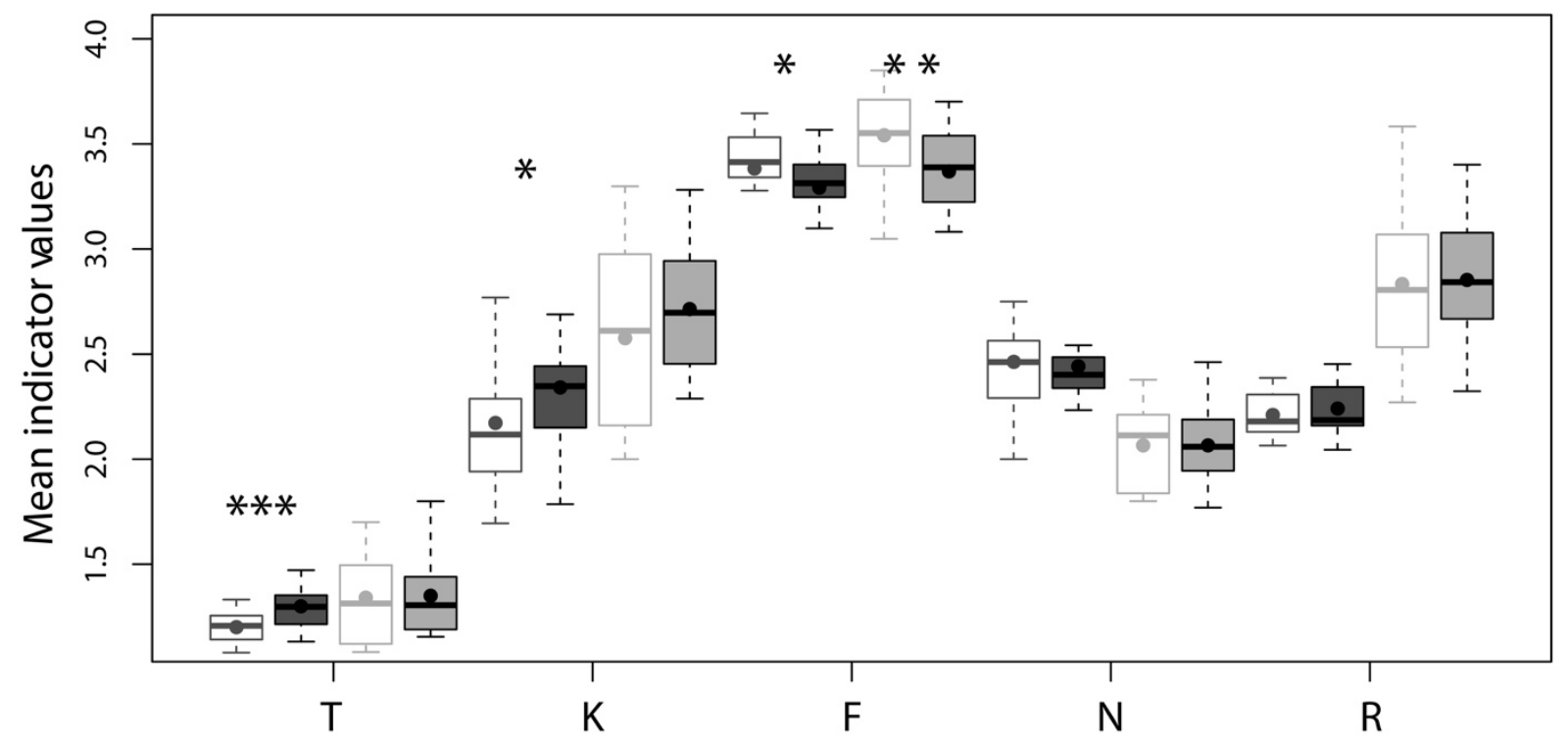

Fig. 7 Cover-weighted means of indicator values (Landolt et al., 2010) for temperature (T), continentality (K), soil humidity $(\mathrm{F})$, nutrient content $(\mathrm{N})$ and $\mathrm{pH}(\mathrm{R})$ in historical (white boxes) and recent inventories of vascular plant species in typical (dark grey) and wet (light grey) snowbeds. Symbols are the same as in Figure 3.

\section{Ecological indicator values}

Acidophilic windy ridges and typical snowbeds showed a significant increase in their mean ecological indicator values for temperature $(T ; p=0.014$ for acidophilic windy ridges, $p<0.001$ for typical snowbeds; Fig. 6) between historical and recent surveys. Windy ridges and snowbeds also differed in terms of other ecological indicator values. The vegetation of windy ridges indicated a shift toward more eutrophic soils ( $\mathrm{N} ; \mathrm{p}<0.001$ for acidophilic, $\mathrm{p}=0.015$ for basophilic windy ridges; Fig. 6 ). The values for soil $\mathrm{pH}$ of the two community types were coherent with their respective position along this ecological gradient, but acidophilic windy ridges showed a significant increase $(p=0.008)$, representing 
a shift towards basophilic windy ridges. The snowbeds showed no significant changes for these indicator values, but the mean continentality values $(K)$ increased between the two inventories in the typical snowbeds ( $p=0.026$; Fig. 7). Simultaneously, the species composition of the snowbeds indicated a trend toward drier conditions ( $p=0.002$ for wet, $p=0.041$ for typical snowbeds). The wet snowbeds now contain a vegetation indicating humidity conditions close to those of the typical snowbeds 23 years ago. No significant difference was observed for the other ecological indicator values (light, humus content) between historical and current surveys.

\section{Discussion}

We observed an increase in biodiversity and biotic homogenisation in snowbeds and on windy ridges, although these changes were not in the same direction. While both communities shifted towards a more thermophilous species composition, as frequently observed in mountains under climate change, the flora of windy ridges indicated more fertile conditions, whereas the snowbeds shifted towards a flora containing less hygrophilous species, preferring more continental conditions.

The $\alpha$-biodiversity increase (Simpson index) and the homogenisation (decrease of $\beta$-diversity) confirmed, with a considerably larger data set, the findings of Matteodo et al. (2016). Both trends have also been observed by various authors in alpine plant communities (e.g., Britton et al. 2009; Carbognani et al. 2014) under climate change. Globally, the climatic changes recorded in the last decades have improved the conditions for plants in the alpine belt, with warmer summer temperatures and longer growing seasons (Rebetez \& Reinhard 2008; Klein et al. 2016; CH2018; Klein et al. 2018). Generalist species or species from neighbouring alpine grasslands could colonise windy ridges and typical snowbeds. These new species are adapted to less extreme conditions in terms of winter temperature and growing season length and, consequently, have mostly higher ecological values for temperature $(T)$ than the species previously growing in these plots. This could explain the observed significant thermophilisation (Gottfried et al. 2012) in two of the four communities that we considered. A similar trend has previously been observed in alpine grasslands (Vittoz et al. 2008; Matteodo et al. 2016) and by numerous authors on alpine summits (e.g., Pauli et al. 2012; Matteodo et al. 2013; Steinbauer et al. 2018) and corresponds to the monotonic relation between species richness and daily maximum temperature (Vonlanthen et al. 2006b). These newcomers increase the $\alpha$-diversity but the more stress-tolerant species (adapted to cope with winter frost on windy ridges and short growing seasons in snowbeds) apparently have not yet been competitively displaced by the newly arriving species (extinction debt; Dullinger et al. 2012). At the same time, some missing specialists (e.g., Agrostis alpina, Phyteuma hemisphaericum on windy ridges; Sagina saginoides, Veronica alpina in snowbeds) colonized the plots, causing the decrease in $\beta$-diversity, as the communities contain more and more the same species (Matteodo et al. 2016).

\section{Windy ridges}

Windy ridges were characterised by a change of flora indicating more eutrophic conditions in both community types, and with less acidic conditions on the acidophilic windy ridges. The increase of $\mathrm{N}$ values can be explained by different factors. (1) It has often been demonstrated that nitrogen deposition induces eutrophication in grasslands (e.g., Stevens et al. 2010; Roth et al. 2015). But the deposition values are low (around $5 \mathrm{~kg} \bullet$ ha $\bullet \mathrm{yr}$ ) in the study area (CFHA 2005; www.bafu.admin.ch) and tended to decrease over the last years, although a cumulative effect cannot be excluded (OFEV 2018). Moreover, eutrophication due to nitrogen deposition is often associated with acidification (Stevens et al. 2010), whereas we observed the opposite in Zermatt. (2) Generalist grassland species tended to increase in cover (Sesleria caerulea) or in frequency (Campanula scheuchzeri, Poa alpina, Festuca violacea aggr., Potentilla aurea, Anthoxanthum alpinum). These increases were rarely significant, but these species have higher $\mathrm{N}$ values than average and, all together, they influence the mean, probably without responding to a real eutrophication. For example, Poa alpina has an $\mathrm{N}$ value of 4 and was previously observed as an efficient colonizer of alpine summits, even in rocky conditions (Vittoz et al. 
2009a; Matteodo et al., 2013). Moreover, species from lower elevations have, on average, higher $\mathrm{N}$ values than alpine species (Odland 2008; Güsewell et al. 2012). (3) Following the significant glacier retreat in the Zermatt region (Rastner et al. 2016), there is a potentially important aeolian dust deposit in the valley (Gisladottir et al. 2005). This loess can be quite nutrient-rich (Küfmann 2003) and might cause soils to evolve towards less oligotrophic conditions.

Aeolian dust deposition is probably an important cause of the observed eutrophication as it can be related to the simultaneous shift of acidophilic windy ridges towards basophilic ones. Indeed, acidophilic windy ridges were characterised by a recent species composition corresponding to less acid soil conditions. This dynamic of windy ridge vegetation has never been highlighted before and could be specific to the study area. The increasing area of glacial moraines and the corresponding increase in aeolian dust in the valley could potentially explain these changes. The geology of the Zermatt region is highly diverse, with numerous basic rocks (calcschists, ultramaphic rocks, marble, etc.) among acidic rocks (Service géologique national 2005). This rock variability is also reflected in the moraines from which the aeolian dust originates. The deposition of aeolian dust, potentially rich in basic cations, on the topsoil of the Zermatt region could be favourable for the establishment of basophilic species. Such dust deposition has been measured in the Central Austrian Alps, where they amounted on average to $\sim 100 \mathrm{~g} \bullet \mathrm{m}^{-2} \bullet \mathrm{a}^{-1}$ (Gruber 1980 in Körner 2003) and were considered as an important buffer of the natural acidity of alpine soils (Küfmann 2003). Indeed, dense clumps of graminoids (e.g., Elyna myosuroidis, Carex sp.), often important in ridge communities, are highly efficient traps for aeolian dust (Steiner 2002; Küfmann 2003).

\section{Snowbeds}

We found that plants originating from neighbouring alpine grasslands had colonized snowbeds (Leontodon helveticus, Festuca halleri aggr., Campanula scheuchzeri), while some of the typical snowbed species tended to decrease in cover over time (Carex lachenalii, C. bicolor, Luzula alpinopilosa). As already observed in previous studies (Carbognani et al. 2014; Sandvik et Odland 2014; Matteodo et al. 2016; Maliniemi et al. 2018), snowbeds have become more similar to alpine grasslands than they were 23 years ago, with a flora indicating drier and more continental conditions than in the past.

The snow cover period, which is the most important environmental filter for snowbeds (Vonlanthen et al. 2006a), has become shorter (Klein et al. 2016) because of lower snowfall (Serquet et al. 2013) and higher spring temperatures. This shorter snow cover duration has several consequences for snowbed vegetation: (1) The growing season is longer, opening the snowbeds to species that require longer periods for growth and reproduction, such as generalists or the typical species of surrounding communities (Braun-Blanquet 1964; Vonlanthen et al. 2006a). One can expect that the colonisation of these species is facilitated by the close proximity of alpine grasslands and snowbeds, which are often distributed as a mosaic in the landscape, depending on the microtopography. (2) Water availability decreases in quantity, and water is available over a shorter period in summer. This particularly affects wet snowbeds, which are mostly irrigated by the melt-water further upslope. A similar trend towards drier conditions were recorded with a smaller data set by Matteodo et al. (2016), and these new conditions are probably the cause of the cover decrease of some typical species of wet snowbeds (Carex bicolor, C. lachenalii). (3) Snow also occurs as a protection against cold nights. With a shorter snow cover period, plants have less protection and have to cope with larger temperature shifts. This corresponds to the increase of the indicator value for continentality, indicating more contrasted temperatures between nights and days. However, according to Klein et al. (2018), the risk of frost after snowmelt has not increased in the last decades.

\section{Conclusions}

Snowbeds and windy ridges in the Zermatt region are both influenced by climate change. Although situated in the same valley, often close to each other, the mechanisms driving their plant community 
changes are different. While increasing temperature seems to be the main driver on windy ridges, the snow cover duration is probably decisive for the dynamics of snowbed communities.

On windy ridges, warmer temperatures probably induce an earlier growth in spring (Vitasse et al. 2017), allowing colonisation by grassland species, which were previously rare because of their high sensitivity to frost compared with specialist species of windy ridges. Moreover, the deposition of nutrients by aeolian dust might also improve the growing conditions for vascular plants. On the other hand, we do not have data indicating that snow cover has decreased on windy ridges, and up to now, there is no visible impact of the shorter snow cover duration on plant species composition. But, in this habitat, snow cover is by definition irregular and the typical species are adapted to deep frosts in winter. Hence, the vegetation of windy ridges seems to have been mainly influenced by temperature increases, either directly or indirectly by dust deposition following the growing areas of glacial moraines.

In snowbeds, the shorter snow cover duration is probably the main driver of vegetation change, by extending the growing season and so enabling taller species from surrounding grasslands to colonise snowbeds or to increase their cover. This might also be caused by reduced water availability in the middle of summer, which might be compounded by projected reductions in summer precipitation in the Alps (CH2018 2018). Although not rich in species, snowbeds shelter many species that are restricted to this habitat, most of them needing humic soils to grow. Therefore, the loss of snowbeds at lower elevations might not be compensated by areas made newly available by warmer conditions or glacier retreat.

This study was restricted to one valley, with particular climatic and geologic conditions. Similar comparisons in other alpine areas would be helpful to obtain a broader view of the present changes in high mountain vegetation under climate change, and the respective influences of other local factors, such as nitrogen deposition and grazing, on vegetation dynamics. Indeed, a good understanding of variation at fine scales and confounding factors are important to improve predictive models of climate change impacts on mountain vegetation. It would be particularly interesting to address the question of aeolian dust deposition, contrasting areas that are poor or rich in recent glacial moraines. Quantification of these deposits are also necessary, since these data are rare in the Alps, although aeolian deposition may play a major role in the soil formation of high alpine areas now available for plant colonisation. Finally, data on climate change impacts on lichens in the Alps are still lacking, with all available studies in Europe until now coming from Scandinavia.

\section{Compliance with ethical standards}

Ethical Statement The authors declare that they respected ethical standards.

Conflict of interest The authors declare that they have no conflict of interest.

Informed consent The investigation in the field was conducted with authorisation of the Burgergemeinde Zermatt. 


\section{Bibliography}

Armitage HF, Britton AJ, van der Wal R., Woodin SJ (2014) The relative importance of nitrogen deposition as a driver of Racomitrium heath species composition and richness across Europe. Biol Conserv 171: 224-231. doi:10.1016/j.biocon.2014.01.039

Borcard D, Gillet F, Legendre P (2011) Numerical ecology with R. Springer, New York

Braun-Blanquet J (1964) Pflanzensoziologie. Grundzüge der Vegetationskunde. Springer, Wien

Britton AJ, Beale CM, Towers W, Hewison RL (2009) Biodiversity gains and losses: Evidence for homogenisation of Scottish alpine vegetation. Biol Conserv 142: 1728-1739. doi:10.1016/j.biocon.2009.03.010

Carbognani M, Tomaselli M, Petraglia A (2014) Current vegetation changes in an alpine late snowbed community in the south-eastern Alps (N-Italy). Alpine Bot 124: 105-113. doi:10.1007/s00035-014-0135-x

CFHA (2005) Les polluants atmosphériques azotés en Suisse. Rapport de la Commission fédérale de l'hygiène de l'air (CFHA). OFEFP, Berne

CH2018 (2018) CH2018 - Climate Scenarios for Switzerland, Technical Report. National Center for Climate Services, Zürich

Clerc P, Truong C (2012) Catalogue des lichens de Suisse. http://www.villege.ch/musinfo/bd/cjb/cataloguelichen. Accessed 17 April 2019

Dullinger S, Gattringer A, Thuiller W et al. (2012) Climate warming, dispersal limitation and extinction debt of European mountain plants. Nat Clim Change 2: 619-622.

Elumeeva TG, Onipchenko VG, Egorov AV, Khubiev AB, Tekeev DK, Soudzilovskaia NA, Cornelissen JHC (2013) Long-term vegetation dynamic in the Northwestern Caucasus: which communities are more affected by upward shifts of plant species? Alpine Bot 123: 77-85. doi:10.1007/s00035-013-0122-7

Friedel H (1961). Schneedeckendauer und Vegetationsverteilung im Gelände. Mitt Forstl Bu Versuchsanstalt Wien 59: 317-369

Gisladottir FO, Arnalds O, Gisladottir G (2005) The effect of landscape and retreating glaciers on wind erosion in south Iceland. Land Degrad Dev 16: 177-187

Gottfried M, Pauli H, Futschik A et al. (2012) Continent wide response of mountain vegetation to climate change. Nat Clim Change 2: 111-115

Gritsch A, Dirnbock T, Dullinger S (2016) Recent changes in alpine vegetation differ among plant communities. J Veg Sci 27: 1177-1186

Güsewell S, Peter M, Birrer S (2012) Altitude modifies species richness-nutrient indicator value relationships in a country-wide survey of grassland vegetation. Ecol Indic 20: 134-142. doi:10.1016/j.ecolind.2012.02.011

Kapfer J, Grytnes JA, Gunnarsson U, Birks HJB (2011) Fine-scale changes in vegetation composition in a boreal mire over 50 years. J Ecol 99: 1179-1189.

Kapfer J, Hédl R, Jurasinski G, Kopecký M, Schei FH, Grytnes JA (2017) Resurveying historical vegetation data opportunities and challenges. Appl Veg Sci 20: 164-171

Käsermann C, Meyer F, Steiner A (2003) Les richesses de la nature en Valais - Le monde végétal de Zermatt. Rotten, Viège

Klein G, Rebetez M, Rixen C, Vitasse Y (2018) Unchanged risk of frost exposure for subalpine and alpine plants after snowmelt in Switzerland despite climate warming. Int J Biometeorol 62: 1755-1762

Klein G, Vitasse Y, Rixen C, Marty C, Rebetez M (2016) Shorter snow cover duration since 1970 in the Swiss Alps due to earlier snowmelt more than to later snow onset. Climatic Change 139: 637-649. doi:10.1007/s10584016-1806-y

Körner C (2003) Alpine plant life. Springer, Berlin

Küfmann C (2003) Soil types and eolian dust in high-mountainous karst of the Northern Calcareous Alps (Zugspitzplatt, Wetterstein Mountains, Germany). Catena 53: 211-227 
Lauber K, Wagner G, Gygax A (2012) Flora Helvetica. Haupt, Bern

Landolt E, Bäumler B, Erhardt A et al. (2010) Flora Indicativa. Ecological indicator values and biological attributes of the Flora of Switzerland and the Alps. Haupt, Berne

Maliniemi T, Kapfer J, Saccone P, Skog A, Virtanen R (2018) Long-term vegetation changes of treeless heath communities in northern Fennoscandia: Links to climate change trends and reindeer grazing. J Veg Sci 29: $469-479$

Matteodo M, Ammann K, Verrecchia EP, Vittoz P (2016) Snowbeds are more affected than other subalpine-alpine plant communities by climate change in the Swiss Alps. Ecol Evol 6: 6969-6982. doi:10.1002/ece3.2354

Matteodo M, Wipf S, Stöckli V, Rixen C, Vittoz P (2013) Elevation gradient of successful plant traits for colonizing alpine summits under climate change. Environ Res Lett 8: 024043. doi:10.1088/1748-9326/8/2/024043

Odland A (2009) Interpretation of altitudinal gradients in South Central Norway based on vascular plants as environmental indicators. Ecol Indic 9: 409-421

OFEV (2018) La qualité de l'air en 2017. Résultats du Réseau national d'observation des polluants atmosphériques (NABEL). OFEV, Bern

Pauli H, Gottfried M, Dullinger S et al. (2012) Recent plant diversity changes on Europe's mountain summits. Science 336: 353-355

Prunier P, Greulich F, Béguin C et al. (2017) Phytosuisse : un référentiel pour les associations végétales de Suisse. https://www.infoflora.ch/fr/milieux/phytosuisse.html. Accessed 17 April 2019

R Core Team (2017) R: a language and environment for statistical computing. R Foundation for Statistical Computing, Vienna. http://www.r-project.org/. Accessed 17 April 2019

Rastner P, Joerg PC, Huss M, Zemp M (2016) Historical analysis and visualization of the retreat of Findelengletscher, Switzerland, 1859-2010. Global Planet Change 145: 67-77. doi:10.1016/j.gloplacha.2016.07.005

Rebetez M, Reinhard M (2008) Monthly air temperature trends in Switzerland 1901-2000 and 1975-2004. Theor Appl Climatol 91: 27-34

Richard JL (1991) Flore et végétation de Zermatt (VS): premier aperçu et réflexions. Bull Murith 109: 27-40

Ross LC, Woodin SJ, Hester AJ, Thompson DBA, Birks HJB (2012) Biotic homogenization of upland vegetation: patterns and drivers at multiple spatial scales over five decades. J Veg Sci 23: 755-770. doi:10.1111/j.16541103.2012.01390.x

Roth T, Kohli L, Rihm B, Amrhein V, Achermann B (2015) Nitrogen deposition and multi-dimensional plant diversity at the landscape scale. Roy Soc Open Sci 2: 150017

Sandvik SM, Odland A (2014) Changes in alpine snowbed-wetland vegetation over three decades in northern Norway. Nord J Bot 32: 377-384. doi: 10.1111/j.1756-1051.2013.00249.x

Serquet G, Marty C, Rebetez M (2013) Monthly trends and the corresponding altitudinal shift in the snowfall/precipitation day ratio. Theor Appl Climatol 114: 437-444. doi:10.1007/s00704-013-0847-7

Service géologique national (2005) Carte géologique de la Suisse 1:500'000. OFEG, Bern-Ittigen

Steinbauer MJ, Grytnes JA, Jurasinski G et al. (2018) Accelerated increase in plant species richness on mountain summits is linked to warming. Nature 556: 231-234. doi:10.1038/s41586-018-0005-6

Steiner A (2002) Die Vegetation der Gemeinde Zermatt. Geobotanica Helvetica 74: 1-204

Stevens CJ, Thompson K, Grime JP, Long CJ, Gowing DJG (2010) Contribution of acidification and eutrophication to declines in species richness of calcifuge grasslands along a gradient of atmospheric nitrogen deposition. Funct Ecol 24: 478-484

Stocker TF, Qin D, Plattner GK et al. (2013) Technical Summary. In: Stocker TF, Qin D, Plattner GK et al. (eds) Climate Change 2013: The Physical Science Basis. Contribution of Working Group I to the Fifth Assessment Report of the Intergovernmental Panel on Climate Change. Cambridge University Press, Cambridge 
Virtanen R, Eskelinen A, Gaare E (2003) Long-term changes in alpine plant communities in Norway and Finland. In: Nagy L, Grabherr G, Körner C, Thompson DBA (eds) Alpine biodiversity in Europe. Springer-Verlag, Berlin, pp. 411-422

Vitasse Y, Rebetez M, Filippa G, Cremonese E, Klein G, Rixen C (2017) 'Hearing' alpine plants growing after snowmelt: ultrasonic snow sensors provide long-term series of alpine plant phenology. Int J Biometeorol 61: 349-361

Vittoz P, Bodin J, Ungricht S, Burga C, Walther GR (2008) One century of vegetation change on Isla Persa, a nunatak in the Bernina massif in the Swiss Alps. J Veg Sci 19: 671-680

Vittoz P, Dussex N, Wassef J, Guisan A (2009a) Diaspore traits discriminate good from weak colonisers on highelevation summits. Basic Appl Ecol 10: 508-515

Vittoz P, Randin CF, Dutoit A, Bonnet F, Hegg O (2009b) Low impact of climate change on subalpine grasslands in the Swiss Northern Alps. Global Change Biol 15: 209-220

Vonlanthen CM, Bühler A, Veit H, Kammer PM, Eugster W (2006a) Alpine plant communities: a statistical assessment of their relation to microclimatological, pedological, geomorphological, and other factors. Phys Geogr 27: 137-154

Vonlanthen CM, Kammer PM, Eugster W, Bühler A, Veit H (2006b) Alpine vascular plant species richness: the importance of daily maximum temperature and $\mathrm{pH}$. Plant Ecol 184 13-25

Additional supporting information in the online version of this article (see "Supplementary Material") contains the following appendices:

Table S1 List of the retained associations with the typical species, the ecological conditions and the number of historical relevés.

Table S2 List of the plots retained in this study, with the classification, the year, authors and number of species, the coordinates, the elevation, the aspect and the slope.

Table S3 Species of the acidophilic windy ridges with a relative frequency change $>15 \%$ and/or a relative cover change $>5 \%$.

Table S4 Species of the basophilic windy ridges with a relative frequency change $>15 \%$ and/or a relative cover change $>5 \%$.

Table S5 Species of the typical snowbeds with a relative frequency change $>15 \%$ and/or a relative cover change $>5 \%$.

Table S6 Species of the wet snowbeds with a relative frequency change $>15 \%$ and/or a relative cover change $>5 \%$.

Fig. S1 Clustering of windy ridge and snowbeds. 


\title{
Supplementary material
}

\section{Contrasting impacts of climate change on the vegetation of windy ridges and snowbeds in the Swiss Alps}

\author{
Loïc Liberati, Swanee Messerli, Magalì Matteodo \& Pascal Vittoz
}

Table S1 List of the retained associations with the generic wording used in the article, the period when the historical inventories were realised (with the median between brackets), the typical species, the ecological conditions, the name of the corresponding associations in Prunier et al. (2017) and the number of historical relevés included in the study.

\begin{tabular}{|c|c|c|c|c|c|}
\hline $\begin{array}{l}\text { Name used in the } \\
\text { article }\end{array}$ & $\begin{array}{l}\text { Period of } \\
\text { the } \\
\text { historical } \\
\text { relevés }\end{array}$ & Main species & $\begin{array}{l}\text { Association (Prunier } \\
\text { et al. 2017) }\end{array}$ & Ecological characteristics & $\begin{array}{l}\text { Number } \\
\text { of } \\
\text { relevés }\end{array}$ \\
\hline \multirow[t]{2}{*}{$\begin{array}{l}\text { Basophilic windy } \\
\text { ridges }\end{array}$} & $\begin{array}{l}1982-1995 \\
(1993)\end{array}$ & $\begin{array}{l}\text { Dominated by Elyna myosuroides, } \\
\text { Silene exscapa, Carex curvula } \\
\text { subsp. rosae, Agrostis alpina and } \\
\text { Sesleria caerulea; characterized by } \\
\text { Minuartia sedoides, Festuca } \\
\text { quadriflora, Carex parviflora, Carex } \\
\text { rupestris and Anthyllis vulneraria } \\
\text { subsp. valesiaca }\end{array}$ & $\begin{array}{l}\text { Elyno-Caricetum } \\
\text { rosae }\end{array}$ & $\begin{array}{l}\text { Windy ridges with surficial } \\
\text { soil, neutral to slightly } \\
\text { acidic }\end{array}$ & 21 \\
\hline & & & $\begin{array}{l}\text { Caricetum } \\
\text { fimbriatae }\end{array}$ & Same, on serpentine & 1 \\
\hline \multirow[t]{2}{*}{$\begin{array}{l}\text { Acidophilic windy } \\
\text { ridges }\end{array}$} & $\begin{array}{l}1980-1995 \\
(1995)\end{array}$ & $\begin{array}{l}\text { Dominated by Elyna myosuroides, } \\
\text { Silene exscapa, Agrostis alpina, } \\
\text { Festuca halleri, Helictotrichon } \\
\text { versicolor, Loiseleuria procumbens, } \\
\text { Lloydia serotina and Carex curvula } \\
\text { s.str. ; characterized by Minuartia } \\
\text { recurva, Luzula lutea, Pulsatilla } \\
\text { vernalis and Veronica bellidioides }\end{array}$ & $\begin{array}{l}\text { Elynetum } \\
\text { myosuroidis }\end{array}$ & $\begin{array}{l}\text { Windy ridges with acidic } \\
\text { soil, often rich in humus }\end{array}$ & 17 \\
\hline & & & $\begin{array}{l}\text { Caricetum curvluae } \\
\text { elynetosum } \\
\text { myosuroidis }\end{array}$ & $\begin{array}{l}\text { Transition between windy } \\
\text { ridges and high-alpine, } \\
\text { acidic grasslands }\end{array}$ & 4 \\
\hline \multirow[t]{3}{*}{ Typical snowbeds } & $\begin{array}{l}\text { 1971-1995 } \\
(1993)\end{array}$ & $\begin{array}{l}\text { Dominated by Alchemilla } \\
\text { pentaphyllea, Salix herbacea, } \\
\text { Gnaphalium supinum, Agrostis }\end{array}$ & Salicetum herbaceae & $\begin{array}{l}\text { Hollows or north-facing } \\
\text { slopes with long snow } \\
\text { cover, with acidic soil }\end{array}$ & 9 \\
\hline & & $\begin{array}{l}\text { rupestris and/or Carex foetida; } \\
\text { characterized by Sibbaldia }\end{array}$ & Caricetum foetidae & $\begin{array}{l}\text { Same, momentary wet in } \\
\text { spring }\end{array}$ & 5 \\
\hline & & $\begin{array}{l}\text { procumbens, Geum montanum and } \\
\text { Sedum alpestre }\end{array}$ & $\begin{array}{l}\text { Polytrichetum } \\
\text { sexangularis }\end{array}$ & $\begin{array}{l}\text { Same, with very long snow } \\
\text { cover }\end{array}$ & 1 \\
\hline \multirow[t]{2}{*}{ Wet snowbeds } & $\begin{array}{l}1989-1995 \\
(1995)\end{array}$ & $\begin{array}{l}\text { Dominated by Carex bicolor and } \\
\text { Salix herbacea; characterized by } \\
\text { Polygonum viviparum, Saxifraga } \\
\text { oppositifolia, Carex parviflora, }\end{array}$ & $\begin{array}{l}\text { Salici herbaceae- } \\
\text { Caricetum lachenalii }\end{array}$ & $\begin{array}{l}\text { Terraces or slopes with } \\
\text { long snow cover, along } \\
\text { small streams or alpine } \\
\text { lakes, with humic soil }\end{array}$ & 12 \\
\hline & & $\begin{array}{l}\text { Sagina saginoides, Ranunculus } \\
\text { glacialis, Sagina saginoides and/or } \\
\text { Carex maritima }\end{array}$ & $\begin{array}{l}\text { Junco triglumis- } \\
\text { Caricetum bicoloris }\end{array}$ & $\begin{array}{l}\text { Same, with little humic } \\
\text { soil, e.g. on glacial } \\
\text { moraine }\end{array}$ & 4 \\
\hline
\end{tabular}


Table S2 List of the plots retained in this study, with the classification in this study (habitat), the code (according to Steiner 2002), the year, authors and number of species for the historical and recent inventories, the coordinates measured in 2016 (GPS Trimble GeoXH, $\pm 1 \mathrm{~m}$; coordinate projection $\mathrm{CH} 1903$ ), the elevation, the aspect, the slope and the original classification (association).

All the floristic data (exhaustive historical and recent relevés) are deposited at Info Flora (www.infoflora.ch).

\begin{tabular}{|c|c|c|c|c|c|c|c|c|c|c|c|c|c|}
\hline \multirow[t]{2}{*}{ Habitat } & \multirow[t]{2}{*}{ Code } & \multicolumn{3}{|c|}{ Historial inventory } & \multicolumn{3}{|c|}{ Recent inventory } & \multicolumn{2}{|c|}{ Coordinates } & \multirow{2}{*}{$\begin{array}{c}\text { Elevation } \\
\text { [m asl] }\end{array}$} & \multicolumn{2}{|c|}{ Aspect Slope } & \multirow[t]{2}{*}{ Association } \\
\hline & & Year & Author & \# spec. & Year & Author(s) & \# spec. & W-E & S-N & & {$\left[{ }^{\circ}\right]$} & {$\left[{ }^{\circ}\right]$} & \\
\hline \multirow{23}{*}{ 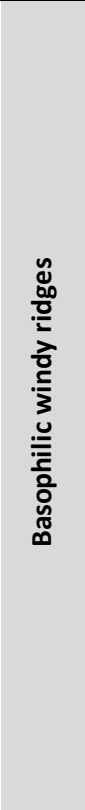 } & 5 & 1995 & F. Meyer & 26 & 2016 & $\begin{array}{l}\text { L. Liberati, S. Messerli, } \\
\text { P. Vittoz }\end{array}$ & 35 & 620808 & 93589 & 2547 & 345 & 20 & Elyno-Caricetum rosae \\
\hline & 23 & 1995 & F. Meyer & 36 & 2016 & 5 L. Liberati, S. Messerli & 51 & 619841 & 93924 & 2465 & 360 & 36 & Elyno-Caricetum rosae \\
\hline & 46 & 1995 & F. Meyer & 42 & 2016 & $\begin{array}{l}\text { L. Liberati, S. Messerli, } \\
\text { P. Vittoz }\end{array}$ & 54 & 620980 & 93900 & 2410 & 360 & 29 & Elyno-Caricetum rosae \\
\hline & 64 & 1995 & F. Meyer & 32 & 2016 & $\begin{array}{l}5 \text { L. Liberati, S. Messerli, } \\
\text { M. Vust }\end{array}$ & 29 & 620171 & 93877 & 2482 & 338 & 30 & Elyno-Caricetum rosae \\
\hline & 68 & 1995 & F. Meyer & 23 & 2016 & 5 L. Liberati & 27 & 620446 & 92935 & 2670 & 358 & 5 & Elyno-Caricetum rosae \\
\hline & 114 & 1995 & F. Meyer & 16 & 2016 & 5 L. Liberati, S. Messerli & 20 & 621044 & 92631 & 2546 & 360 & 0 & Elyno-Caricetum rosae \\
\hline & 178 & 1995 & F. Meyer & 11 & 2016 & 5 L. Liberati & 16 & 621602 & 92417 & 2645 & 325 & 10 & Elyno-Caricetum rosae \\
\hline & 189 & 1995 & F. Meyer & 20 & 2016 & 5 L. Liberati & 21 & 620262 & 93382 & 2684 & 308 & 8 & Elyno-Caricetum rosae \\
\hline & 222 & 1995 & F. Meyer & 27 & 2016 & 5 L. Liberati & 27 & 622390 & 91385 & 2811 & 340 & 8 & Elyno-Caricetum rosae \\
\hline & 234 & 1995 & F. Meyer & 21 & 2016 & 5 L. Liberati & 23 & 622264 & 91532 & 2765 & 360 & 0 & Elyno-Caricetum rosae \\
\hline & 238 & 1995 & F. Meyer & 20 & 2016 & 5 L. Liberati & 28 & 622498 & 91502 & 2758 & 5 & 5 & Elyno-Caricetum rosae \\
\hline & 1134 & 1993 & S. Reist & 37 & 2016 & 5 L. Liberati, S. Messerli & 32 & 626742 & 98187 & 2556 & 5 & 30 & Elyno-Caricetum rosae \\
\hline & 1172 & 1993 & S. Reist & 49 & 2016 & 5 L. Liberati & 67 & 626389 & 96424 & 2421 & 335 & 15 & Elyno-Caricetum rosae \\
\hline & 1189 & 1993 & S. Reist & 45 & 2016 & 5 L. Liberati & 41 & 626999 & 96965 & 2638 & 290 & 25 & Elyno-Caricetum rosae \\
\hline & 3210 & 1993 & C. Käsermann & 30 & 2016 & 5 L. Liberati & 50 & 621944 & 98029 & 2539 & 250 & 42 & Elyno-Caricetum rosae \\
\hline & 3414 & 1993 & C. Käsermann & 16 & 2016 & 5 L. Liberati & 20 & 621301 & 96446 & 2776 & 310 & 18 & Elyno-Caricetum rosae \\
\hline & 4368 & 1982 & J.-L. Richard & 23 & 2016 & 5 L. Liberati & 24 & 624296 & 92500 & 2697 & 270 & 17 & Caricetum fimbriatae \\
\hline & 4754 & 1985 & J.-L. Richard & 29 & 2016 & 5 L. Liberati & 40 & 620186 & 93648 & 2569 & 345 & 30 & Elyno-Caricetum rosae \\
\hline & 4755 & 1985 & J.-L. Richard & 28 & 2016 & 5 L. Liberati & 37 & 620189 & 93485 & 2630 & 338 & 28 & Elyno-Caricetum rosae \\
\hline & 4835 & 1986 & J.-L. Richard & 31 & 2016 & 5 L. Liberati & 36 & 626183 & 93451 & 2791 & 360 & 17 & Elyno-Caricetum rosae \\
\hline & 4839 & 1986 & J.-L. Richard & 14 & 2016 & 5 L. Liberati & 19 & 626455 & 93065 & 2943 & 270 & 8 & Elyno-Caricetum rosae \\
\hline & 4930 & 1987 & J.-L. Richard & 17 & 2016 & 5 L. Liberati & 16 & 626218 & 93439 & 2809 & 340 & 32 & Elyno-Caricetum rosae \\
\hline & 5215 & 1992 & J.-L. Richard & 47 & 2016 & 5 L. Liberati, S. Messerli & 65 & 621880 & 97179 & 2488 & 360 & 38 & Elyno-Caricetum rosae \\
\hline \multirow{20}{*}{ 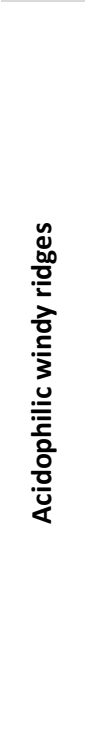 } & 13 & 1995 & F. Meyer & 23 & 2016 & $\begin{array}{l}5 \text { L. Liberati, S. Messerli, } \\
\text { P. Vittoz }\end{array}$ & 26 & 621002 & 93819 & 2455 & 34 & 8 & Elynetum myosuroidis \\
\hline & 14 & 1995 & F. Meyer & 25 & 2016 & 5 L. Liberati, S. Messerli & 28 & 620873 & 93822 & 2450 & 330 & 20 & Elynetum myosuroidis \\
\hline & 29 & 1995 & F. Meyer & 35 & 2016 & 5 L. Liberati & 42 & 621305 & 92582 & 2556 & 360 & 5 & Elynetum myosuroidis \\
\hline & 62 & 1995 & F. Meyer & 26 & 2016 & 5 L. Liberati & 29 & 620307 & 93695 & 2556 & 10 & 8 & Elynetum myosuroidis \\
\hline & 67 & 1995 & F. Meyer & 21 & 2016 & 5 L. Liberati & 28 & 620434 & 92880 & 2673 & 160 & 8 & Elynetum myosuroidis \\
\hline & 75 & 1995 & F. Meyer & 21 & 2016 & 5 L. Liberati & 30 & 622027 & 92423 & 2610 & 340 & 25 & Elynetum myosuroidis \\
\hline & 76 & 1995 & F. Meyer & 33 & 2016 & 5 L. Liberati, S. Messerli & 34 & 622021 & 92586 & 2560 & 56 & 30 & Caricetum curvulae elynetosum \\
\hline & 119 & 1995 & F. Meyer & 15 & 2016 & 5 L. Liberati & 23 & 621010 & 92308 & 2682 & 60 & 8 & Caricetum curvulae elynetosum \\
\hline & 135 & 1995 & F. Meyer & 24 & 2016 & 5 L. Liberati, S. Messerli & 37 & 619966 & 94060 & 2434 & 320 & 20 & Elynetum myosuroidis \\
\hline & 184 & 1995 & F. Meyer & 23 & 2016 & 5 L. Liberati, S. Messerli & 29 & 621832 & 92933 & 2480 & 12 & 18 & Elynetum myosuroidis \\
\hline & 185 & 1995 & F. Meyer & 16 & 2016 & 5 L. Liberati & 26 & 620508 & 93107 & 2650 & 390 & 5 & Caricetum curvulae elynetosum \\
\hline & 186 & 1995 & F. Meyer & 27 & 2016 & 5 L. Liberati & 39 & 620371 & 93318 & 2673 & 50 & 18 & Elynetum myosuroidis \\
\hline & 200 & 1995 & F. Meyer & 21 & 2016 & 5 L. Liberati & 23 & 621155 & 93625 & 2486 & 35 & 17 & Elynetum myosuroidis \\
\hline & 230 & 1995 & F. Meyer & 17 & 2016 & 5 L. Liberati, S. Messerli & 24 & 620660 & 93717 & 2514 & 50 & 5 & Elynetum myosuroidis \\
\hline & 1076 & 1993 & S. Reist & 42 & 2016 & $\begin{array}{l}\text { L. Liberati, S. Messerli, } \\
\text { P. Vittoz }\end{array}$ & 48 & 626415 & 96224 & 2484 & 310 & 10 & Elynetum myosuroidis \\
\hline & 2001 & 1993 & S. Krähenmann & 37 & 2016 & $\begin{array}{l}5 \text { L. Liberati, S. Messerli, } \\
\text { P. Vittoz }\end{array}$ & 46 & 629128 & 95656 & 2643 & 320 & 30 & Elynetum myosuroidis \\
\hline & 2075 & 1993 & S. Krähenmann & 39 & 2016 & 5 L. Liberati & 46 & 628449 & 95489 & 2524 & 340 & 35 & Elynetum myosuroidis \\
\hline & 2077 & 1993 & S. Krähenmann & 40 & 2016 & 5 L. Liberati & 48 & 628387 & 95439 & 2539 & 345 & 40 & Elynetum myosuroidis \\
\hline & 2078 & 1993 & S. Krähenmann & 31 & 2016 & $\begin{array}{l}5 \text { L. Liberati, S. Messerli, } \\
\text { P. Vittoz }\end{array}$ & 45 & 628767 & 95544 & 2560 & 335 & 30 & Elynetum myosuroidis \\
\hline & 2080 & 1993 & S. Krähenmann & 45 & 2016 & 5 L. Liberati & 45 & 628681 & 95488 & 2565 & 350 & 40 & Elynetum myosuroidis \\
\hline
\end{tabular}




\begin{tabular}{|c|c|c|c|c|c|c|c|c|c|c|c|c|c|}
\hline \multirow[t]{2}{*}{ Habitat } & \multirow[t]{2}{*}{ Code } & \multicolumn{3}{|c|}{ Historial inventory } & \multicolumn{3}{|c|}{ Recent inventory } & \multicolumn{2}{|c|}{ Coordinates } & \multirow{2}{*}{$\begin{array}{c}\text { Elevation } \\
\text { [m asl] }\end{array}$} & \multicolumn{2}{|c|}{ Aspect Slope } & \multirow[t]{2}{*}{ Association } \\
\hline & & Year & Author & \# spec. & Year & Author(s) & \# spec. & W-E & S-N & & {$\left[{ }^{\circ}\right]$} & {$\left[{ }^{\circ}\right]$} & \\
\hline \multirow{15}{*}{$\begin{array}{l}\frac{n}{0} \\
\dot{d} \\
\frac{0}{3} \\
0 \\
\frac{0}{5} \\
\frac{0}{\pi} \\
\frac{0}{2}\end{array}$} & 19 & 1995 & F. Meyer & 27 & 2016 & S. Messerli & 23 & 620899 & 93609 & 2526 & 25 & 20 & Caricetum foetidae \\
\hline & 59 & 1995 & F. Meyer & 11 & 2016 & S. Messerli & 14 & 620348 & 93648 & 2554 & 0 & 0 & Salicetum herbaceae \\
\hline & 210 & 1995 & F. Meyer & 9 & 2016 & S. Messerli & 13 & 622989 & 91141 & 2821 & 0 & 0 & Caricetum foetidae \\
\hline & 2040 & 1993 & S. Krähenmann & 14 & 2016 & S. Messerli & 23 & 630389 & 96009 & 2816 & 240 & 5 & Caricetum foetidae \\
\hline & 2149 & 1993 & S. Krähenmann & 13 & 2016 & S. Messerli & 25 & 628687 & 96431 & 2883 & 0 & 0 & Salicetum herbaceae \\
\hline & 2176 & 1993 & S. Krähenmann & 16 & 2016 & S. Messerli & 31 & 628590 & 96479 & 2884 & 0 & 0 & Salicetum herbaceae \\
\hline & 2733 & 1971 & J.-L. Richard & 11 & 2016 & $\begin{array}{l}\text { S. Messerli, L. Liberati, } \\
\text { M. Matteodo }\end{array}$ & 18 & 620720 & 93410 & 2542 & 0 & 0 & Caricetum foetidae \\
\hline & 3027 & 1993 & C. Käsermann & 19 & 2016 & S. Messerli, L. Liberati & 25 & 621486 & 97462 & 2461 & 15 & 25 & Salicetum herbaceae \\
\hline & 3034 & 1993 & C. Käsermann & 11 & 2016 & S. Messerli & 16 & 622359 & 98459 & 2721 & 310 & 25 & Salicetum herbaceae \\
\hline & 3060 & 1993 & C. Käsermann & 13 & 2016 & S. Messerli, L. Liberati & 20 & 621642 & 97028 & 2605 & 340 & 15 & Salicetum herbaceae \\
\hline & 3061 & 1993 & C. Käsermann & 9 & 2016 & S. Messerli & 17 & 621757 & 96879 & 2625 & 30 & 2 & Salicetum herbaceae \\
\hline & 3076 & 1993 & C. Käsermann & 16 & 2016 & S. Messerli & 28 & 621100 & 99040 & 2608 & 0 & 0 & Salicetum herbaceae \\
\hline & 3336 & 1993 & C. Käsermann & 9 & 2016 & S. Messerli & 13 & 622017 & 98813 & 2755 & 0 & 0 & Caricetum foetidae \\
\hline & 3671 & 1993 & C. Käsermann & 12 & 2016 & S. Messerli & 25 & 622392 & 99075 & 2756 & 190 & 8 & Salicetum herbaceae \\
\hline & 4924 & 1992 & J.-L. Richard & 8 & 2016 & S. Messerli & 12 & 627149 & 92830 & 3002 & 190 & 8 & Polytrichetum sexangularis \\
\hline \multirow{16}{*}{ 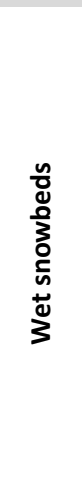 } & 104 & 1995 & F. Meyer & 8 & 2016 & S. Messerli & 8 & 619533 & 93691 & 2554 & 0 & 0 & Junco triglumis-Caricetum bicoloris \\
\hline & 116 & 1995 & F. Meyer & 18 & 2016 & S. Messerli & 24 & 621025 & 92450 & 2619 & 30 & 38 & Salici herbaceae-Caricetum lachenalii \\
\hline & 118 & 1995 & F. Meyer & 20 & 2016 & S. Messerli & 21 & 621063 & 92335 & 2660 & 70 & 25 & Salici herbaceae-Caricetum lachenalii \\
\hline & 183 & 1995 & F. Meyer & 16 & 2016 & S. Messerli & 21 & 621572 & 92488 & 2591 & 360 & 20 & Salici herbaceae-Caricetum lachenalii \\
\hline & 187 & 1995 & F. Meyer & 13 & 2016 & S. Messerli & 19 & 620333 & 93347 & 2680 & 25 & 5 & Junco triglumis-Caricetum bicoloris \\
\hline & 224 & 1995 & F. Meyer & 16 & 2016 & S. Messerli & 17 & 622504 & 91393 & 2786 & 45 & 7 & Salici herbaceae-Caricetum lachenalii \\
\hline & 233 & 1995 & F. Meyer & 14 & 2016 & S. Messerli & 30 & 622246 & 91484 & 2775 & 340 & 8 & Salici herbaceae-Caricetum lachenalii \\
\hline & 236 & 1995 & F. Meyer & 14 & 2016 & S. Messerli & 12 & 622194 & 91654 & 2727 & 0 & 0 & Salici herbaceae-Caricetum lachenalii \\
\hline & 262 & 1995 & F. Meyer & 12 & 2016 & S. Messerli & 18 & 622166 & 91698 & 2720 & 35 & 4 & Junco triglumis-Caricetum bicoloris \\
\hline & 264 & 1995 & F. Meyer & 16 & 2016 & S. Messerli & 22 & 621995 & 91964 & 2686 & & & Salici herbaceae-Caricetum lachenalii \\
\hline & 1119 & 1993 & S. Reist & 10 & 2016 & S. Messerli & 17 & 627449 & 97212 & 2928 & 305 & 3 & Salici herbaceae-Caricetum lachenalii \\
\hline & 3178 & 1993 & C. Käsermann & 23 & 2016 & S. Messerli & 30 & 621601 & 98187 & 2457 & 0 & 0 & Salici herbaceae-Caricetum lachenalii \\
\hline & 4535 & 1992 & J.-L. Richard & 14 & 2016 & S. Messerli & 24 & 624886 & 92413 & 2747 & 5 & 360 & Salici herbaceae-Caricetum lachenalii \\
\hline & 4541 & 1992 & J.-L. Richard & 15 & 2016 & S. Messerli & 31 & 622325 & 91975 & 2614 & 0 & 0 & Salici herbaceae-Caricetum lachenalii \\
\hline & 4645 & 1992 & J.-L. Richard & 22 & 2016 & S. Messerli & 25 & 622356 & 98977 & 2752 & 180 & 2 & Salici herbaceae-Caricetum lachenalii \\
\hline & 8380 & 1989 & B. Bressoud & 7 & 2016 & S. Messerli & 18 & 624840 & 92435 & 2740 & 0 & 0 & Junco triglumis-Caricetum bicoloris \\
\hline
\end{tabular}


Table S3 Species of the acidophilic windy ridges with a relative frequency change $>15 \%$ (upper part of the table) and/or a relative cover change $>5 \%$ (lower part of the table). Species with less important changes are not retained in the table. Significant changes, according to a permutation test, are in bold.

\begin{tabular}{|c|c|c|c|c|c|c|c|c|c|}
\hline Species & Habitat (Landolt et al. 2010) & $\begin{array}{c}\text { Relative } \\
\text { historical } \\
\text { frequency } \\
\text { [\%] }\end{array}$ & $\begin{array}{c}\text { Relative } \\
\text { recent } \\
\text { frequency } \\
{[\%]}\end{array}$ & $\begin{array}{c}\text { Difference } \\
\text { of } \\
\text { frequency } \\
\text { [\%] }\end{array}$ & $\begin{array}{c}\text { Frequency } \\
\text { p-value }\end{array}$ & $\begin{array}{c}\text { Mean } \\
\text { historical } \\
\text { relative } \\
\text { cover [\%] }\end{array}$ & $\begin{array}{c}\text { Mean } \\
\text { recent } \\
\text { relative } \\
\text { cover [\%] } \\
\end{array}$ & $\begin{array}{c}\text { Difference } \\
\text { of cover } \\
{[\%]}\end{array}$ & $\begin{array}{c}\text { Cover } p- \\
\text { value }\end{array}$ \\
\hline Euphrasia minima & Acidophilic alpine grasslands & 26.3 & 73.7 & 47.4 & 0.002 & 1.4 & 0.5 & -0.9 & 0.762 \\
\hline Leontodon helveticus & Acidophilic alpine grasslands & 26.3 & 52.6 & 26.3 & 0.099 & 3.5 & 0.5 & -2.9 & 0.329 \\
\hline Selaginella selaginoides & Basophilic alpine grasslands & 31.6 & 57.9 & 26.3 & 0.087 & 0.9 & 0.5 & -0.5 & 0.869 \\
\hline Erigeron uniflorus & Acidophilic alpine grasslands & 5.3 & 31.6 & 26.3 & 0.111 & 0.1 & 0.4 & 0.4 & - \\
\hline Poa alpina & Eutrophic grasslands & 26.3 & 52.6 & 26.3 & 0.113 & 1.0 & 1.7 & 0.8 & 0.812 \\
\hline Androsace obtusifolia & Acidophilic alpine grasslands & 36.8 & 63.2 & 26.3 & 0.100 & 1.4 & 0.5 & -0.9 & 0.740 \\
\hline Antennaria carpatica & Windy ridges & 63.2 & 84.2 & 21.1 & 0.092 & 1.2 & 1.1 & -0.2 & 0.957 \\
\hline Phyteuma hemisphaericum & Windy ridges & 21.1 & 42.1 & 21.1 & 0.155 & 1.3 & 0.3 & -1.0 & - \\
\hline Veronica fruticans & Rocks and screes & 0.0 & 21.1 & 21.1 & 0.195 & 0.0 & 0.5 & 0.5 & - \\
\hline Minuartia verna & Dry grasslands & 0.0 & 21.1 & 21.1 & 0.157 & 0.0 & 0.6 & 0.6 & - \\
\hline Homogyne alpina & Acidophilic alpine grasslands & 31.6 & 52.6 & 21.1 & 0.210 & 3.1 & 2.1 & -1.0 & 0.719 \\
\hline Potentilla crantzii & Basophilic alpine grasslands & 10.5 & 31.6 & 21.1 & 0.207 & 1.4 & 0.9 & -0.5 & - \\
\hline Veronica aphylla & Windy ridges & 5.3 & 26.3 & 21.1 & 0.201 & 0.5 & 0.7 & 0.2 & - \\
\hline Gentiana brachyphylla & Windy ridges & 42.1 & 63.2 & 21.1 & 0.232 & 0.9 & 0.5 & -0.4 & 0.900 \\
\hline Agrostis alpina & Windy ridges & 68.4 & 84.2 & 15.8 & 0.217 & 8.1 & 7.5 & -0.7 & 0.821 \\
\hline Loiseleuria procumbens & Heathlands & 57.9 & 73.7 & 15.8 & 0.200 & 24.0 & 18.1 & -5.9 & 0.090 \\
\hline Hieracium piliferum aggr. & Acidophilic alpine grasslands & 52.6 & 68.4 & 15.8 & 0.295 & 1.0 & 1.7 & 0.7 & 0.796 \\
\hline Galium anisophyllon & Basophilic alpine grasslands & 0.0 & 15.8 & 15.8 & 0.318 & 0.0 & 0.6 & 0.6 & - \\
\hline Pyrola minor & Heathlands & 0.0 & 15.8 & 15.8 & 0.319 & 0.0 & 0.3 & 0.3 & - \\
\hline Potentilla aurea & Acidophilic alpine grasslands & 10.5 & 26.3 & 15.8 & 0.358 & 1.4 & 0.6 & -0.8 & - \\
\hline Achillea nana & Rocks and screes & 42.1 & 57.9 & 15.8 & 0.368 & 0.7 & 0.6 & -0.1 & 0.984 \\
\hline Salix serpillifolia & Windy ridges & 47.4 & 63.2 & 15.8 & 0.381 & 6.1 & 2.6 & -3.6 & 0.258 \\
\hline \multicolumn{10}{|l|}{$\ldots$} \\
\hline Polygala alpestris & Basophilic alpine grasslands & 15.8 & 0.0 & -15.8 & 0.345 & 0.6 & 0.0 & -0.6 & - \\
\hline Salix breviserrata & Shrublands & 10.5 & 10.5 & 0.0 & 1.000 & 11.9 & 24.0 & 12.2 & - \\
\hline Elyna myosuroides & Windy ridges & 89.5 & 100.0 & 10.5 & 0.452 & 13.9 & 19.4 & 5.5 & 0.099 \\
\hline Lotus corniculatus aggr. & Basophilic alpine grasslands & 15.8 & 26.3 & 10.5 & 0.565 & 3.2 & 8.7 & 5.5 & - \\
\hline Carex curvula s.str. & Acidophilic alpine grasslands & 42.1 & 36.8 & -5.3 & 0.781 & 10.6 & 15.6 & 5.1 & 0.101 \\
\hline$\ldots$ & & & & & & & & & \\
\hline Lloydia serotina & Windy ridges & 89.5 & 89.5 & 0.0 & 1.000 & 6.8 & 1.7 & -5.1 & 0.108 \\
\hline Carex curvula subsp. rosae & Windy ridges & 10.5 & 5.3 & -5.3 & 0.728 & 12.5 & 4.1 & -8.4 & - \\
\hline Carex sempervirens & Basophilic alpine grasslands & 10.5 & 15.8 & 5.3 & 0.789 & 16.7 & 8.0 & -8.6 & - \\
\hline Astragalus alpinus & Basophilic alpine grasslands & 5.3 & 0.0 & -5.3 & 0.768 & 14.7 & 0.0 & -14.7 & - \\
\hline
\end{tabular}


Table S4 Species of the basophilic windy ridges with a relative frequency change $>15 \%$ (upper part of the table) and/or a relative cover change $>5 \%$ (lower part of the table). Species with less important changes are not retained in the table. Significant changes, according to a permutation test, are in bold.

\begin{tabular}{|c|c|c|c|c|c|c|c|c|c|}
\hline Species & $\begin{array}{l}\text { Habitat (Landolt et al. } \\
\text { 2010) }\end{array}$ & $\begin{array}{c}\text { Relative } \\
\text { historical } \\
\text { frequency } \\
\text { [\%] }\end{array}$ & $\begin{array}{c}\text { Relative } \\
\text { recent } \\
\text { frequency } \\
{[\%]}\end{array}$ & $\begin{array}{c}\text { Difference } \\
\text { of } \\
\text { frequency } \\
\text { [\%] }\end{array}$ & $\begin{array}{l}\text { Frequency } \\
\text { p-value }\end{array}$ & $\begin{array}{c}\text { Mean } \\
\text { historical } \\
\text { relative } \\
\text { cover [\%] }\end{array}$ & $\begin{array}{c}\text { Mean } \\
\text { recent } \\
\text { relative } \\
\text { cover [\%] }\end{array}$ & $\begin{array}{c}\text { Difference } \\
\text { of cover } \\
{[\%]}\end{array}$ & $\begin{array}{l}\text { Cover } p- \\
\text { value }\end{array}$ \\
\hline Euphrasia minima & Acidophilic alpine grasslands & 29.2 & 66.7 & 37.5 & 0.004 & 3.7 & 0.6 & -3.0 & 0.281 \\
\hline Campanula scheuchzeri & Basophilic alpine grasslands & 37.5 & 66.7 & 29.2 & 0.009 & 0.7 & 0.5 & -0.2 & 0.947 \\
\hline Agrostis alpina & Windy ridges & 54.2 & 83.3 & 29.2 & 0.023 & 4.8 & 5.6 & 0.8 & 0.771 \\
\hline Festuca violacea aggr. & Basophilic alpine grasslands & 29.2 & 50.0 & 20.8 & 0.109 & 2.1 & 6.8 & 4.7 & 0.101 \\
\hline Phyteuma hemisphaericum & Windy ridges & 0.0 & 20.8 & 20.8 & 0.102 & 0.0 & 0.3 & 0.3 & - \\
\hline Gentiana campestris s.str. & Acidophilic alpine grasslands & 4.2 & 25.0 & 20.8 & 0.115 & 0.5 & 0.5 & 0.0 & - \\
\hline Salix herbacea & Snowbeds & 12.5 & 29.2 & 16.7 & 0.165 & 0.9 & 1.0 & 0.0 & - \\
\hline Oxytropis helvetica & Basophilic alpine grasslands & 16.7 & 33.3 & 16.7 & 0.172 & 11.0 & 9.2 & -1.8 & - \\
\hline Juncus jacquinii & Acidophilic alpine grasslands & 12.5 & 29.2 & 16.7 & 0.149 & 4.4 & 0.5 & -3.9 & - \\
\hline Anthoxanthum alpinum & Acidophilic alpine grasslands & 4.2 & 20.8 & 16.7 & 0.204 & 0.5 & 0.8 & 0.3 & - \\
\hline Poa alpina & Eutrophic grasslands & 54.2 & 70.8 & 16.7 & 0.223 & 1.2 & 1.5 & 0.3 & 0.919 \\
\hline Salix serpillifolia & Windy ridges & 45.8 & 62.5 & 16.7 & 0.203 & 3.7 & 3.9 & 0.2 & 0.926 \\
\hline Veronica aphylla & Windy ridges & 4.2 & 20.8 & 16.7 & 0.220 & 3.3 & 0.4 & -2.8 & - \\
\hline $\begin{array}{l}\text { Festuca halleri aggr. } \\
\text {... }\end{array}$ & Acidophilic alpine grasslands & 25.0 & 41.7 & 16.7 & 0.203 & 6.3 & 3.0 & -3.3 & 0.215 \\
\hline Carex ericetorum & Windy ridges & 50.0 & 29.2 & -20.8 & 0.099 & 5.7 & 1.7 & -4.0 & 0.153 \\
\hline Carex fimbriata & Basophilic alpine grasslands & 4.2 & 4.2 & 0.0 & 1.000 & 41.9 & 49.9 & 8.1 & - \\
\hline Sesleria caerulea & Basophilic alpine grasslands & 45.8 & 45.8 & 0.0 & 1.000 & 8.7 & 15.4 & 6.7 & 0.030 \\
\hline $\begin{array}{l}\text { Erigeron uniflorus } \\
\ldots\end{array}$ & Acidophilic alpine grasslands & 20.8 & 20.8 & 0.0 & 1.000 & 1.0 & 6.5 & 5.5 & - \\
\hline Silene exscapa & Rocks and screes & 91.7 & 91.7 & 0.0 & 1.000 & 9.5 & 4.0 & -5.5 & 0.074 \\
\hline Festuca laevigata & Basophilic alpine grasslands & 4.2 & 4.2 & 0.0 & 1.000 & 13.4 & 0.4 & -13.0 & - \\
\hline
\end{tabular}


Table S5 Species of the typical snowbeds with a relative frequency change > 15\% (upper part of the table) and/or a relative cover change $>5 \%$ (lower part of the table). Species with less important changes are not retained in the table. Significant changes, according to a permutation test, are in bold.

\begin{tabular}{|c|c|c|c|c|c|c|c|c|c|}
\hline Species & $\begin{array}{l}\text { Habitat (Landolt et al. } \\
\text { 2010) }\end{array}$ & $\begin{array}{c}\text { Relative } \\
\text { historical } \\
\text { frequency } \\
\text { [\%] }\end{array}$ & $\begin{array}{c}\text { Relative } \\
\text { recent } \\
\text { frequency } \\
\text { [\%] }\end{array}$ & $\begin{array}{c}\text { Difference } \\
\text { of } \\
\text { frequency } \\
\text { [\%] }\end{array}$ & $\begin{array}{l}\text { Frequency } \\
p \text {-value }\end{array}$ & $\begin{array}{c}\text { Mean } \\
\text { historical } \\
\text { relative } \\
\text { cover [\%] }\end{array}$ & $\begin{array}{c}\text { Mean } \\
\text { recent } \\
\text { relative } \\
\text { cover [\%] }\end{array}$ & $\begin{array}{c}\text { Difference } \\
\text { of cover } \\
{[\%]}\end{array}$ & $\begin{array}{l}\text { Cover } p- \\
\text { value }\end{array}$ \\
\hline Leontodon helveticus & Acidophilic alpine grasslands & 20.0 & 60.0 & 40.0 & 0.020 & 2.4 & 1.3 & -1.1 & - \\
\hline Festuca halleri aggr. & Acidophilic alpine grasslands & 26.7 & 66.7 & 40.0 & 0.027 & 5.1 & 1.4 & -3.7 & 0.601 \\
\hline Sagina saginoides & Snowbeds & 0.0 & 40.0 & 40.0 & 0.030 & 0.0 & 0.6 & 0.6 & - \\
\hline Gnaphalium supinum & Snowbeds & 53.3 & 86.7 & 33.3 & 0.059 & 9.2 & 4.6 & -4.6 & 0.477 \\
\hline Veronica alpina & Snowbeds & 60.0 & 93.3 & 33.3 & 0.060 & 3.2 & 2.2 & -1.0 & 0.89 \\
\hline Agrostis schraderiana & Acidophilic alpine grasslands & 13.3 & 40.0 & 26.7 & 0.139 & 1.9 & 11.5 & 9.6 & - \\
\hline Festuca violacea aggr. & Basophilic alpine grasslands & 13.3 & 40.0 & 26.7 & 0.144 & 2.5 & 1.5 & -1.0 & - \\
\hline Cirsium spinosissimum & Ruderal areas & 13.3 & 40.0 & 26.7 & 0.155 & 0.6 & 1.7 & 1.1 & - \\
\hline Phleum alpinum aggr. & Eutrophic grasslands & 6.7 & 26.7 & 20.0 & 0.298 & 0.4 & 10.0 & 9.6 & - \\
\hline Anthoxatum odoratum & Acidophilic alpine grasslands & 0.0 & 20.0 & 20.0 & 0.299 & 0.0 & 2.1 & 2.1 & - \\
\hline Minuartia sedoides & Acidophilic alpine grasslands & 20.0 & 40.0 & 20.0 & 0.301 & 21.6 & 7.1 & -14.6 & - \\
\hline Geum montanum & Acidophilic alpine grasslands & 33.3 & 53.3 & 20.0 & 0.301 & 1.1 & 3.1 & 2.0 & 0.787 \\
\hline Carex curvula s.str. & Acidophilic alpine grasslands & 33.3 & 53.3 & 20.0 & 0.303 & 4.8 & 3.1 & -1.7 & 0.777 \\
\hline Cerastium cerastoides & Snowbeds & 40.0 & 60.0 & 20.0 & 0.304 & 1.1 & 0.7 & -0.4 & 0.955 \\
\hline Phyteuma hemisphaericum & Windy ridges & 6.7 & 26.7 & 20.0 & 0.305 & 0.0 & 0.4 & 0.4 & - \\
\hline Senecio incanus s.str. & Acidophilic alpine grasslands & 0.0 & 20.0 & 20.0 & 0.305 & 0.0 & 0.5 & 0.5 & - \\
\hline Deschampsia cespitosa & Eutrophic grasslands & 0.0 & 6.7 & 6.7 & 0.730 & 0.0 & 18.2 & 18.2 & - \\
\hline Nardus stricta & Acidophilic alpine grasslands & 40.0 & 53.3 & 13.3 & 0.363 & 1.3 & 7.9 & 6.6 & 0.347 \\
\hline$\ldots$ & & & & & & & & & \\
\hline Alchemilla pentaphyllea & Snowbeds & 86.7 & 93.3 & 6.7 & 0.868 & 25.0 & 19.4 & -5.6 & 0.384 \\
\hline Salix herbacea & Snowbeds & 73.3 & 86.7 & 13.3 & 0.321 & 29.2 & 23.3 & -6.0 & 0.383 \\
\hline Cerastium pedunculatum & Rocks and screes & 6.7 & 0.0 & -6.7 & 0.729 & 6.4 & 0.0 & -6.4 & - \\
\hline Carex foetida & Snowbeds & 66.7 & 66.7 & 0.0 & 1.000 & 26.2 & 18.9 & -7.3 & 0.282 \\
\hline Carex lachenalii & Snowbeds & 13.3 & 6.7 & -6.7 & 0.722 & 11.6 & 0.6 & -11.0 & - \\
\hline Luzula alpinopilosa & Snowbeds & 6.7 & 6.7 & 0.0 & 1.000 & 13.3 & 0.8 & -12.5 & - \\
\hline Minuartia sedoides & Acidophilic alpine grasslands & 20.0 & 40.0 & 20.0 & 0.301 & 21.6 & 7.1 & -14.6 & - \\
\hline
\end{tabular}


Table S6 Species of the wet snowbeds with a relative frequency change $>15 \%$ (upper part of the table) and/or a relative cover change $>5 \%$ (lower part of the table). Species with less important changes are not retained in the table. Significant changes, according to a permutation test, are in bold.

\begin{tabular}{|c|c|c|c|c|c|c|c|c|c|}
\hline Species & $\begin{array}{l}\text { Habitat (Landolt et al. } \\
\text { 2010) }\end{array}$ & $\begin{array}{c}\text { Relative } \\
\text { historical } \\
\text { frequency } \\
\text { [\%] }\end{array}$ & $\begin{array}{c}\text { Relative } \\
\text { recent } \\
\text { frequency } \\
\text { [\%] }\end{array}$ & $\begin{array}{c}\text { Difference } \\
\text { of } \\
\text { frequency } \\
\text { [\%] }\end{array}$ & $\begin{array}{l}\text { Frequency } \\
\text { p-value }\end{array}$ & $\begin{array}{c}\text { Mean } \\
\text { historical } \\
\text { relative } \\
\text { cover [\%] }\end{array}$ & $\begin{array}{c}\text { Mean } \\
\text { recent } \\
\text { relative } \\
\text { cover [\%] }\end{array}$ & $\begin{array}{c}\text { Difference } \\
\text { of cover } \\
{[\%]}\end{array}$ & $\begin{array}{c}\text { Cover } p- \\
\text { value }\end{array}$ \\
\hline Veronica alpina & Snowbeds & 25.0 & 62.5 & 37.5 & 0.020 & 2.3 & 0.8 & -1.5 & 0.813 \\
\hline Leontodon helveticus & Acidophilic alpine grasslands & 18.8 & 56.3 & 37.5 & 0.022 & 2.0 & 0.7 & -1.3 & - \\
\hline Campanula scheuchzeri & Basophilic alpine grasslands & 6.3 & 37.5 & 31.3 & 0.066 & 1.1 & 0.4 & -0.7 & - \\
\hline Pedicularis kerneri & Acidophilic alpine grasslands & 6.3 & 31.3 & 25.0 & 0.132 & 1.1 & 0.5 & -0.6 & - \\
\hline Carex sempervirens & Basophilic alpine grasslands & 0.0 & 25.0 & 25.0 & 0.134 & 0.0 & 8.0 & 8.0 & - \\
\hline Euphrasia minima & Acidophilic alpine grasslands & 25.0 & 50.0 & 25.0 & 0.144 & 0.3 & 1.1 & 0.8 & 0.92 \\
\hline Sagina saginoides & Snowbeds & 37.5 & 56.3 & 18.8 & 0.261 & 2.5 & 0.9 & -1.6 & 0.808 \\
\hline Salix serpillifolia & Windy ridges & 0.0 & 18.8 & 18.8 & 0.264 & 0.0 & 1.6 & 1.6 & - \\
\hline Carex bicolor & Wetlands & 50.0 & 68.8 & 18.8 & 0.272 & 20.3 & 9.0 & -11.4 & 0.117 \\
\hline Festuca quadriflora & Basophilic alpine grasslands & 6.3 & 25.0 & 18.8 & 0.279 & 4.4 & 1.2 & -3.2 & - \\
\hline Lotus corniculatus aggr. & Basophilic alpine grasslands & 6.3 & 25.0 & 18.8 & 0.285 & 0.5 & 0.5 & 0.0 & - \\
\hline Gnaphalium supinum & Snowbeds & 18.8 & 37.5 & 18.8 & 0.288 & 2.5 & 3.1 & 0.5 & - \\
\hline Agrostis rupestris & Acidophilic alpine grasslands & 6.3 & 25.0 & 18.8 & 0.291 & 3.3 & 3.9 & 0.6 & - \\
\hline Leucanthemopsis alpina & Acidophilic alpine grasslands & 25.0 & 43.8 & 18.8 & 0.291 & 0.3 & 0.6 & 0.3 & 0.965 \\
\hline Trifolium badium & Basophilic alpine grasslands & 0.0 & 18.8 & 18.8 & 0.295 & 0.0 & 1.4 & 1.4 & - \\
\hline $\begin{array}{l}\text { Soldanella alpina } \\
\ldots\end{array}$ & Eutrophic grasslands & 0.0 & 18.8 & 18.8 & 0.297 & 0.0 & 1.7 & 1.7 & - \\
\hline Carex lachenalii & Snowbeds & 56.3 & 37.5 & -18.8 & 0.285 & 10.9 & 10.5 & -0.4 & 0.951 \\
\hline Androsace alpina & Rocks and screes & 18.8 & 0.0 & -18.8 & 0.302 & 0.7 & 0.0 & -0.7 & - \\
\hline Carex capillaris & Basophilic alpine grasslands & 12.5 & 12.5 & 0.0 & 1.000 & 8.6 & 28.0 & 19.4 & - \\
\hline Festuca rubra aggr. & Alpine/eutrophic grasslands & 0.0 & 6.3 & 6.3 & 0.819 & 0.0 & 12.9 & 12.9 & - \\
\hline Nardus stricta & Acidophilic alpine grasslands & 6.3 & 6.3 & 0.0 & 1.000 & 3.3 & 12.9 & 9.7 & - \\
\hline Homogyne alpina & Acidophilic alpine grasslands & 0.0 & 12.5 & 12.5 & 0.490 & 0.0 & 8.5 & 8.5 & - \\
\hline Carex nigra & Wetlands & 0.0 & 6.3 & 6.3 & 0.821 & 0.0 & 8.3 & 8.3 & - \\
\hline Juncus triglumis & Wetlands & 25.0 & 18.8 & -6.3 & 0.819 & 6.5 & 13.4 & 7.0 & - \\
\hline Anthoxatum odoratum & Acidophilic alpine grasslands & 0.0 & 12.5 & 12.5 & 0.512 & 0.0 & 6.9 & 6.9 & - \\
\hline $\begin{array}{l}\text { Trifolium pallescens } \\
\text {... }\end{array}$ & Rocks and screes & 0.0 & 6.3 & 6.3 & 0.821 & 0.0 & 5.3 & 5.3 & - \\
\hline Saxifraga aizoides & Wetlands & 12.5 & 25.0 & 12.5 & 0.539 & 8.6 & 1.6 & -7.0 & - \\
\hline Luzula alpinopilosa & Snowbeds & 18.8 & 31.3 & 12.5 & 0.552 & 11.9 & 3.7 & -8.2 & - \\
\hline Deschampsia cespitosa & Eutrophic grasslands & 12.5 & 12.5 & 0.0 & 1.000 & 21.3 & 7.2 & -14.2 & - \\
\hline Carex frigida & Wetlands & 6.3 & 6.3 & 0.0 & 1.000 & 16.4 & 0.9 & -15.5 & - \\
\hline Salix hastata & Shrublands & 6.3 & 6.3 & 0.0 & 1.000 & 31.8 & 5.3 & -26.5 & - \\
\hline
\end{tabular}



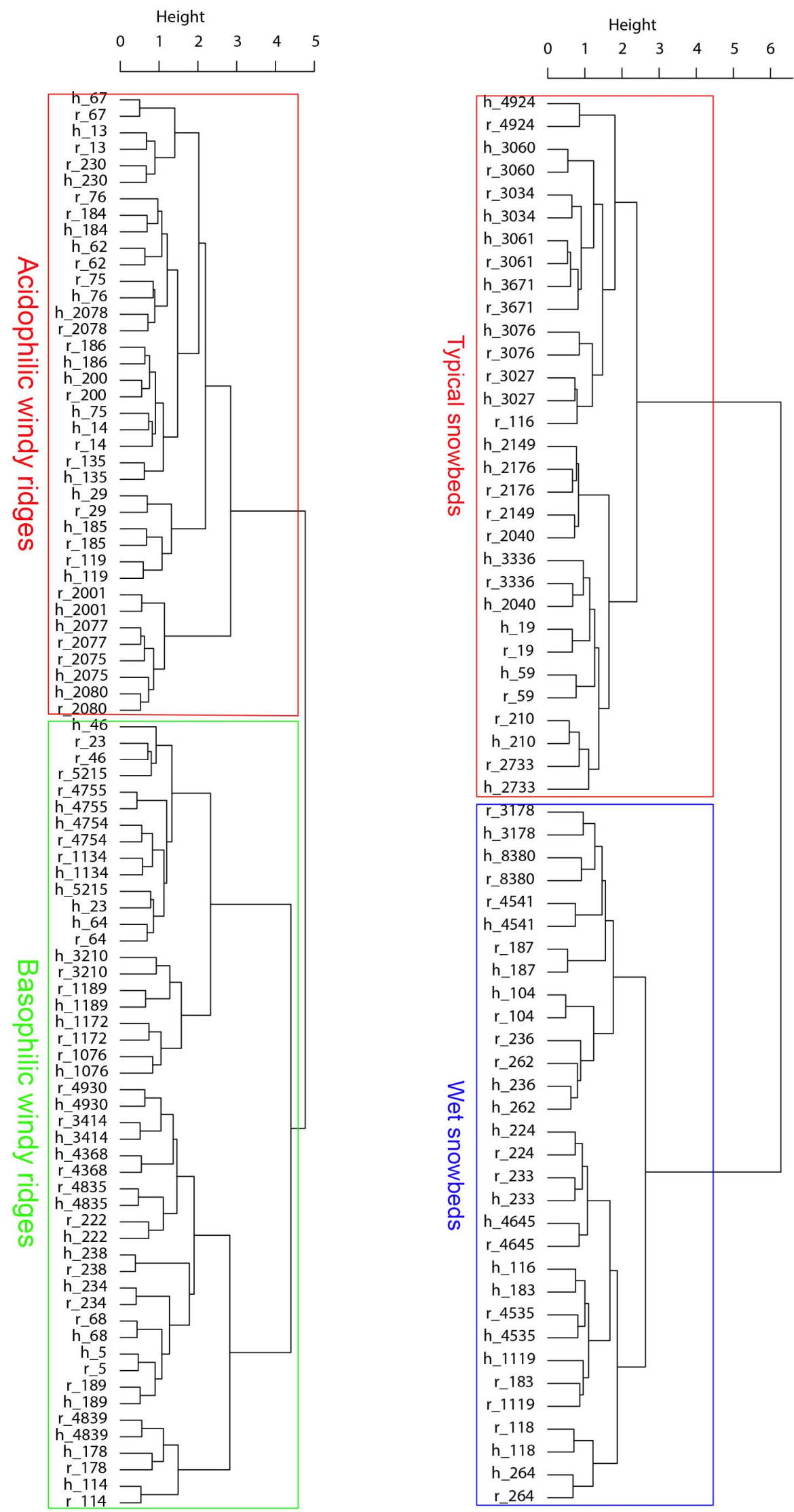

All the plots of windy ridges stay in the same group between historical and recent inventories.

Among the snowbeds, the plot 116 shifted from wet to typical snowbeds.

Fig. S1 Clustering of windy ridge (left) and snowbed (right) plots based on Hellinger distance and Ward aggregation. Historical (Steiner 2002) inventories are preceded by $h$ and recent ones by $r$. 